\title{
Stretching and Contraction of Extensional Basins With Pre-Rift Salt: A Numerical Modeling Approach
}

\author{
Pablo Granado ${ }^{1 *}$, Jonas B. Ruh ${ }^{2 *}$, Pablo Santolaria ${ }^{1}$, Philipp Strauss $^{1}$ and \\ Josep Anton Muñoz ${ }^{1}$
}

1 Geomodels Research Institute, Departament de Dinàmica de la Terra i de L'Oceà, Universitat de Barcelona, Barcelona, Spain, ${ }^{2}$ Structural Geology and Tectonics Group, Geological Institute, Department of Earth Sciences, ETH Zürich, Zurich, Switzerland

We present a series of 2D thermo-mechanical numerical experiments of thick-skinned crustal extension including a pre-rift salt horizon and subsequent thin-, thick-skinned, or mixed styles of convergence accompanied by surface processes. Extension localization along steep basement faults produces half-graben structures and leads to variations in the original distribution of pre-rift salt. Thick-skinned extension rate and salt

OPEN ACCESS

Edited by:

Fabien Graveleau,

Université de Lille, France

Reviewed by:

Anthony Jourdon,

Total, France

Naiara Fernandez,

University of Texas at Austin,

United States

${ }^{*}$ Correspondence:

Pablo Granado

pablomartinez_granado@ub.edu

Jonas B. Ruh

jonas.ruh@erdw.ethz.ch

Specialty section:

This article was submitted to Structural Geology and Tectonics, a section of the journal

Frontiers in Earth Science

Received: 02 January 2021

Accepted: 22 February 2021

Published: 15 April 2021

Citation:

Granado P, Ruh JB, Santolaria P,

Strauss $P$ and Muñoz JA (2021)

Stretching and Contraction

of Extensional Basins With Pre-Rift

Salt: A Numerical Modeling Approach.

Front. Earth Sci. 9:648937.

doi: 10.3389/feart.2021.648937 rheology control hanging wall accommodation space as well as the locus and timing of minibasin grounding. Upon shortening, extension-related basement steps hinder forward propagation of evolving shallow thrust systems; conversely, if full basin inversion takes place along every individual fault, the regional salt layer is placed back to its preextensional configuration, constituting a regionally continuous décollement. Continued shortening and basement involvement deform the shallow fold-thrust structures and locally breaches the shallow décollement. We aim at obtaining a series of structural, stratigraphic and kinematic templates of fold-and-thrust belts involving rift basins with an intervening pre-rift salt horizon. Numerical results are compared to natural cases of salt-related inversion tectonics to better understand their structural evolution.

Keywords: finite-difference, salt tectonics, rifting, minibasin, depositional architecture, tectonic inversion, foldand-thrust belts

\section{INTRODUCTION}

It is well known that the inherited structural framework and the distribution of décollement-prone units have a strong influence on the structural style of fold-and-thrust belts and their kinematic evolution (Ruh et al., 2012; Granado et al., 2016; Lacombe and Bellahsen, 2016; Tavani et al., 2021). A significant leap in the understanding of fold-and-thrust belts (Boyer and Elliot, 1982) came with the incorporation of thrust tectonics involving the positive inversion of rift basins and passive margins (e.g., Gillcrist et al., 1987; Granado and Ruh, 2019; Ruh, 2019). Salt tectonics concepts have been more recently incorporated and provide key concepts in terms of related geometries and kinematics (see Jackson and Hudec, 2017 for a recent thorough review), particularly when early salt structures become involved in the thrust wedge (e.g., Rowan and Vendeville, 2006; Jahani et al., 2007; Callot et al., 2012; Callot et al., 2012; Duffy et al., 2018; Granado et al., 2019; Célini et al., 2020).

Salt is well known for being an extremely efficient décollement (Davis and Engelder, 1985), whose inherent weakness allows for relatively fast flow at geological rates in response to load 
gradients. The strength of salt is strain rate dependent, thus being extremely sensitive to rates of extension, contraction and/or surficial processes such as sedimentation and erosion (i.e., differential loading; see Hudec and Jackson, 2007). Two types of salt response to stress have been proposed largely based on experimental research: linear viscous and temperaturedependent non-Newtonian. However, since direct measurements of rheology at natural deformation rates are not feasible, the rheology of rock salt during long-term deformation in nature is still controversial ( $\mathrm{Li}$ et al., 2012). Little is known as to how such differing rheologies may impact stratigraphic patterns resulting from salt evacuation coeval to deformation and structural styles developed during extension and convergence (see Rowan et al., 2019 for a recent review). In fact, wellconstrained natural examples may show characteristics at odds with the mechanical behavior of salt proposed from laboratory experiments (Li and Urai, 2012).

In this work, we briefly review the archetypal geometries of extensional half-graben basins with a pre-rift salt layer, and those formed after their subsequent shortening (Figure 1). We have chosen this model geometry configuration, since it defines many Late Paleozoic to Mesozoic inverted basins and the structural style of fold-and-thrust belts incorporating such basins (Soto et al., 2017). We describe a series of numerical modeling experiments of extension followed by thin-skinned, thick-skinned, or mixed (i.e., thin- to thick-skinned) deformation styles of shortening. Although the use of a simplified "layecake" stratigraphy allows for quick balanced cross-sections construction and validation, such template is overwhelmly misused and leads to systematic errors in structural definition and de-risking (e.g., Pérez-Díaz et al., 2020). We aim at obtaining a series of process-based stratigraphic and structural templates to aid in subsurface characterization. Our templates may be also applied to other salt-influenced rift basins and passive margins to fold-and-thrust belts where the initial relationships between basement features responsible for crustal stretching/thinning and their sedimentary cover have been lost due to large tectonic transport. Our modeling results are discussed and compared to two natural case studies: the Moroccan Atlas and the Calcareous Alps of Austria.

\section{EXTENSION AND INVERSION OF RIFT BASINS INVOLVING PRE-RIFT SALT}

\section{Processes and Rationale for Numerical Modeling \\ Extension}

In the following, we describe the archetypical structural styles of rift basins involving pre-rift salt affected by thick-skinned (i.e., basement-involved) extensional faulting (Figure 1A). The simplest scenario denotes the mechanical decoupling between basement faults and a supra-salt sedimentary cover imposed by the presence of an intervening salt horizon. In such a scenario, the most common structures are monoclines and forced folds developed above the propagating basement faults (see Coleman et al., 2019 for a recent review). The degree of (de-)coupling between basement and cover and the formation of associated fault-related folds is controlled by: (i) extensional fault displacement rate, (ii) salt rheology, (iii) salt layer thickness vs. fault displacement, and (iv) thickness and mechanical properties of the supra-salt cover (e.g., Withjack and Callaway, 2000; Richardson et al., 2005; Tavani and Granado, 2015). Since weak salt can inhibit the propagation of basement faults to the suprasalt cover, the latter accommodates extension by stretching and folding (e.g., Tavani et al., 2018). Thin-skinned extension and/or erosion of the upper hinge of developing forced folds (Figure 1B) can trigger the initiation of diapirism. In addition, differential loading associated with sedimentation focused on the subsiding hanging wall of basement-involved faults favor the expulsion of underlying salt and further upwelling of salt, whereas syn-extensional sediments onlap onto the supra-salt cover (Figure 1C). In detail, these processes should be recorded by the minibasin broad infill architecture, but also by the interactions at the salt-sediment interface for which the relative rates between salt rise and sediment supply would be reflected on the sedimentary record of halokinetic sequences (see Roca et al., 2021 for a recent review). Salt evacuation eventually leads to the primary basal welding of hanging wall minibasins (Figure 1C), whereas deflation of any remaining salt results in the lateral shift of depocentres (e.g., flip-flop kinematics sensu Quirk and Pilcher, 2012; Figure 1D).

\section{Inversion and Crustal Shortening}

In systems undergoing convergence, shortening can take place by: (i) thin-skinned deformation where the cover is strongly decoupled from basement deformation in the orogenic hinterland (Figure 1E), (ii) thick-skinned tectonics involving the positive inversion of the basement faults and coupling between basement and cover deformation (Figure 1F), (iii) thick- and thin-skinned shortening where the cover is moderately decoupled from the shortened basement.

Common structural styles typical of inverted basins may include hanging wall by-pass thrusts, footwall shortcut thrusts, back-thrusts, and harpoon anticlines (see Granado and Ruh, 2019 for a recent review). However, due to the inherent weakness of salt rock, diapirs, and salt walls will be squeezed upon contraction leading to additional salt rise, surface flaring as allochthonous salt, and/or salt export back to the source layer (Dooley et al., 2009; Duffy et al., 2018). Eventually, salt diapirs will be pinched-off to form secondary welds and then thrusts nucleate within and propagate from the tip of underlying diapir pedestals (Figures 1E,F); additional regional shortening and displacement along thrust welds could lead to further minibasin rotation and imbrication. Full shortening may transport all these structures forelandward, also leading internal deformation of minibasins. At least conceptually, stress concentration at basement steps may result into the nucleation of new thrusts or favor buttressing against extensional faults. Conversely, if full basin inversion occurs for each individual basement fault, i.e., the basement top is reset to its pre-extensional configuration, a flat lying décollement will favor forelandward slipping of the supra-salt strata. More complex evolutions may take place in thin- to thick-skinned 


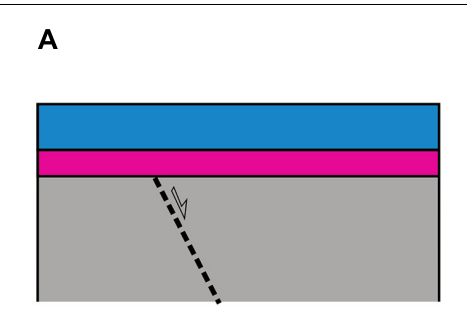

B

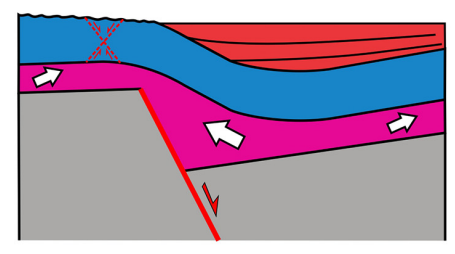

C

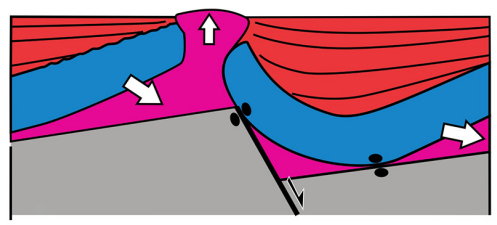

D

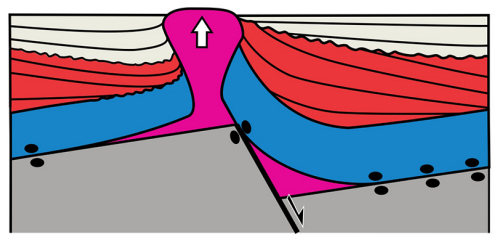

E

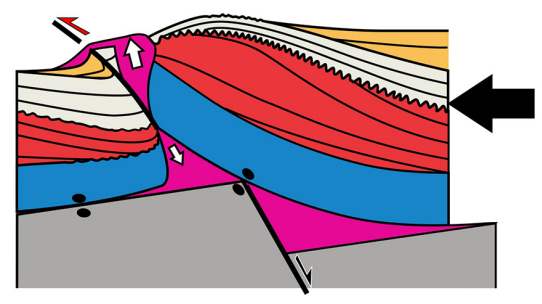

F

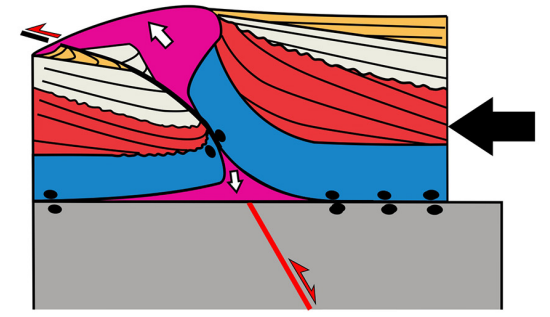

FIGURE 1 | Archetypal geometries of extensional half-graben basins with a pre-rift salt layer (magenta), and those formed after their subsequent shortening. (A) Pre-rift configuration. (B) Thick-skinned extensional forced fold, with lapping syn-extension sediments (red) on a pre-kinematic cover (blue). (C) Thick-skinned extension, diapirism, and local welding of the pre-kinematic cover. (D) After thick-skinned extension and local welding, sediment loading induces further salt evacuation and depocenters shift (i.e., flip-flop). (E) Thin-skinned convergence. (F) Thick-skinned convergence and full basin inversion. Yellow sediments are syn-convergence deposits. Black paired dots represent salt welds, white arrows indicate main salt flow.

convergence scenarios, particularly when surface processes (i.e., syn-convergence erosion and sedimentation) are present.

Previous numerical modeling studies on salt tectonics have been carried out in the last years, dealing with whole passive margin salt tectonics processes (e.g., Albertz et al., 2010; Allen and Beaumont, 2012; Gradmann et al., 2012; Allen et al., 2020; Duretz et al., 2020), the formation of minibasins (Peel, 20; Fernández N. et al., 2020), the role of thick-skinned extension (e.g., Burliga et al., 2012). However, there is limited modeling work addressing both the extensional phase and the subsequent shortening phase of an inverted salt basin; our work here aims to link geometries (i.e., partially observable in seismic data or in outcrop) to specific tectono-stratigraphic processes to better understand natural processes of deformation, as well as to reduce uncertainty in exploration and extraction of natural resources and/or storage.

\section{NUMERICAL MODEL}

Experiments of extension and subsequent convergence are conducted by applying a 2D finite difference thermo-mechanical numerical code with a fully staggered Eulerian grid and a freely advecting Lagrangian marker field containing the necessary material parameters (Ruh, 2017; Ruh and Vergés, 2018).

\section{Governing Equations}

The mechanical model is based on the Stokes equation implying conservation of momentum and the continuity equation implying conservation of mass under the assumption of incompressibility:

$$
\frac{-\partial P}{\partial x_{i}}+\frac{\partial \tau_{i j}}{\partial x_{j}}=\rho g_{i}
$$

$$
\frac{\partial u_{i}}{\partial x_{i}}=0
$$

$\mathrm{P}$ denotes dynamic pressure (mean stress), $\tau_{i j}$ is the twodimensional deviatoric stress tensor, $\rho$ is rock density, $\mathrm{g}_{i}$ is the gravitational acceleration $\left(\mathrm{g}_{1}=0 ; \mathrm{g}_{2}=9.81 \mathrm{~m}^{2} / \mathrm{s}\right), \mathrm{u}_{i}$ denote velocities in $\mathrm{x}$ - and $\mathrm{y}$-direction, and $\mathrm{x}_{i}$ are spatial coordinates $\left(\mathrm{x}_{1}=\mathrm{x}, \mathrm{x}_{2}=\mathrm{y}\right)$.

The thermal model is based on the energy equation:

$$
\rho C_{P}\left(\frac{D T}{D t}\right)=k \frac{\partial^{2} T}{\partial x_{i}^{2}}
$$

where $\mathrm{T}$ denotes temperature, $\mathrm{t}$ is time, $\mathrm{C}_{p}$ is heat capacity, and $\mathrm{k}$ the thermal conductivity coefficient. Additional heat terms such as radioactive heating and shear heating are neglected in the thermal equation due to the geometrical constraints of the model setup and related boundary conditions that affect the diffusion of such additional heat. We assume that the initial thermal conditions of the crust are at steady state. The mechanical and thermal models are separately solved on the Eulerian nodes with Matlab's "backslash" direct solver. The resulting pressure field from the mechanical model and the resulting temperature field from the energy equation are interpolated with a linear distance-weighted scheme onto the Lagrangian makers. The Lagrangian markers then advect through the Eulerian according to a fourth-order Runge-Kutta interpolation of the calculated two-directional velocity field.

\section{Numerical Implementation}

The visco-elastic rheological model is defined by a Maxwell-type strain-stress relationship with a combined viscous and elastic 
description of strain rate:

$$
\dot{\varepsilon}_{\mathrm{ij}}=\frac{1}{2 \eta} \tau_{\mathrm{ij}}+\frac{1}{2 \mathrm{G}} \frac{\mathrm{D} \tau_{\mathrm{ij}}}{\mathrm{Dt}}
$$

where $\eta$ is the effective viscosity and $G$ the elastic modulus. The objective co-rotational time derivative of visco-elastic stresses is discretized as a first-order finite difference function (see Moresi et al., 2003, 2007; Gerya and Yuen, 2007):

$$
\frac{D \tau_{i j}}{D t}=\frac{\tau_{i j}-\tau_{i j}{ }^{\text {old }}}{\Delta t_{e}}
$$

Effective viscosity $\eta$ is calculated for temperature- and stressdependent non-Newtonian dislocation creep:

$$
\eta=0.5 \cdot \frac{1}{A_{D}} \cdot \tau_{I I}^{(1-n)} \cdot \exp \left(\frac{Q}{R T}\right)
$$

where the second invariant of the stress tensor is given by $\tau_{I I}=$ $\sqrt{\frac{1}{2}} \tau_{i j}^{2}$, $\mathrm{R}$ is the gas constant, $\mathrm{A}_{D}$ is the pre-exponential factor, $\mathrm{n}$ the power-law constant, and $\mathrm{Q}$ the thermal activation energy. Elasticity is implemented by a modification of the viscous stresses depending on the stress history and an "elastic" time step of $\Delta \mathrm{t}_{e}=5 \mathrm{kyr}$. The updated visco-elastic deviatoric stresses are defined by:

$$
\tau_{\mathrm{ij}}=2 \eta \dot{\varepsilon}_{\mathrm{ij}} \mathrm{Z}+\tau_{\mathrm{ij}}^{\mathrm{old}}(1-\mathrm{Z})
$$

where superscript "old" indicates stresses of the previous time step and $\mathrm{Z}$ denotes the visco-elasticity factor

$$
\mathrm{Z}=\frac{\Delta \mathrm{t}_{\mathrm{e}} \cdot \mathrm{G}}{\eta+\Delta \mathrm{t}_{\mathrm{e}} \cdot \mathrm{G}}
$$

The effective viscosity $\eta$ is multiplied by this visco-elastic factor to obtain a numerical viscosity $\eta_{\text {num }}$ that is used to solve the set of equations:

$$
\eta_{\text {num }}=\eta \cdot Z=\frac{\eta \cdot \Delta t_{e} \cdot G}{\eta+\Delta t_{e} \cdot G}
$$

Plastic deformation is implemented according to the DruckerPrager yield criterion and applies if the visco-elastic second invariant of the stress tensor $\sigma_{I I}$ exceeds the yield stress $\sigma_{y}$ (if $F>0)$ :

$$
\begin{gathered}
\mathbf{F}=\sigma_{\mathrm{II}}-\sigma_{\mathrm{y}} \\
\sigma_{y}=\mathbf{P} \cdot(1-\lambda) \cdot \sin \varphi+\mathrm{C} \cdot \cos \varphi
\end{gathered}
$$

where $\mathrm{C}$ denotes cohesion, $\varphi$ is the friction angle, and $\lambda$ the fluid pressure ratio defined as fluid pressure divided by mean stress, $\mathrm{P}_{f} / \mathrm{P}$. If $F>0$, exceeded stresses are reduced to remain within the failure envelope:

$$
\begin{aligned}
& \sigma_{\mathrm{xx}}^{\text {new }}=\sigma_{\mathrm{xx}} \frac{\sigma_{\mathrm{y}}}{\sigma_{\mathrm{II}}} \\
& \sigma_{\mathrm{xy}}^{\text {new }}=\sigma_{\mathrm{xy}} \frac{\sigma_{\mathrm{y}}}{\sigma_{\mathrm{II}}}
\end{aligned}
$$

Effective viscosity $\eta$ is capped to maintain yield stresses:

$$
\eta=\frac{\sigma_{\mathrm{y}}}{2 \dot{\varepsilon}_{I I}}
$$

where,

$$
\dot{\varepsilon}_{\mathrm{II}}=\sqrt{\frac{1}{2} \dot{\varepsilon}_{\mathrm{ij}}^{2}}
$$

Viscosity, including the visco-elastic effect and plastic failure, is calculated on Lagrangian markers and interpolated onto the Eulerian nodes with a weighted-distance averaging scheme to solve the system of equations. Picard iterations (repeated cycles of global solution) are performed until the average velocity change is smaller than $10^{-14} \mathrm{~m} / \mathrm{s}$.

\section{Geometrical Setup}

The numerical model is designed to investigate crustal extension along steep normal faults accompanied by syn-extensional deposition into an evolving half-graben system and subsequent tectonic inversion. The Eulerian grid measures $150 \mathrm{~km} \times 25 \mathrm{~km}$ with $1501 \times 251$ nodes in $\mathrm{x}$ - and $\mathrm{y}$-direction, respectively, resulting in a nodal resolution of $100 \mathrm{~m} \times 100 \mathrm{~m}$ (Figure 2). Each nodal cell contains nine randomly distributed Lagrangian markers defining the rock type and carrying material parameters. The initial marker distribution prescribes $15 \mathrm{~km}$ of upper continental crust at the bottom overlain by a 1-km-thick salt horizon and a $0.5-\mathrm{km}$-thick mechanically strong horizon (Figure 2A). The upper $8.5 \mathrm{~km}$ of the model domain are filled with sticky-air markers to assure very low shear stresses along the rock-air interface (Crameri et al., 2012). Five fault zones are predefined in the upper $10 \mathrm{~km}$ of the crustal basement $(y=10-$ $20 \mathrm{~km}$ ) to enhance strain localization. These fault zones reach the basement-salt interface at $x=30,50,70,90$, and $110 \mathrm{~km}$ (Figure 2A). The fault zones are initially $400 \mathrm{~m}$ wide and dip $60^{\circ}$ to the right. Crustal basement and basement faults exhibit a nonNewtonian temperature-dependent rheology, where the relative weakness of pre-existing faults is given by a lower frictional strength (Table 1). While pre- and syn-kinematic cover sequence rock types have a linear pre-failure viscosity of $10^{24} \mathrm{~Pa} \cdot \mathrm{s}$. The rheology of salt is either linear viscous $\left(10^{18} \mathrm{~Pa} \cdot \mathrm{s}\right)$ or temperaturedependent non-Newtonian. Density, linear and non-Newtonian viscosity parameters, elastic modulus, friction angle, cohesion, and fluid pressure ratio of all rock types and sticky-air are given in Table 1. Effective viscosities are cut off to not fall below $10^{17} \mathrm{~Pa} \cdot \mathrm{s}$ or exceed $10^{24} \mathrm{~Pa} \cdot \mathrm{s}$, comparable to the range of typical rock viscosities (Ranali, 1997), to prevent large viscosity ranges that would lead to difficulties in solving the system of equations. The initial temperature field describes a linear geothermal gradient of $33.3^{\circ} \mathrm{C} / \mathrm{km}$ that results in a temperature of $550^{\circ} \mathrm{C}$ at the base of the model (e.g., Turcotte and Schubert, 2002; Artemieva, 2011); this rather elevated thermal gradient implies steady state thermal equilibration of a mature continental crust. 


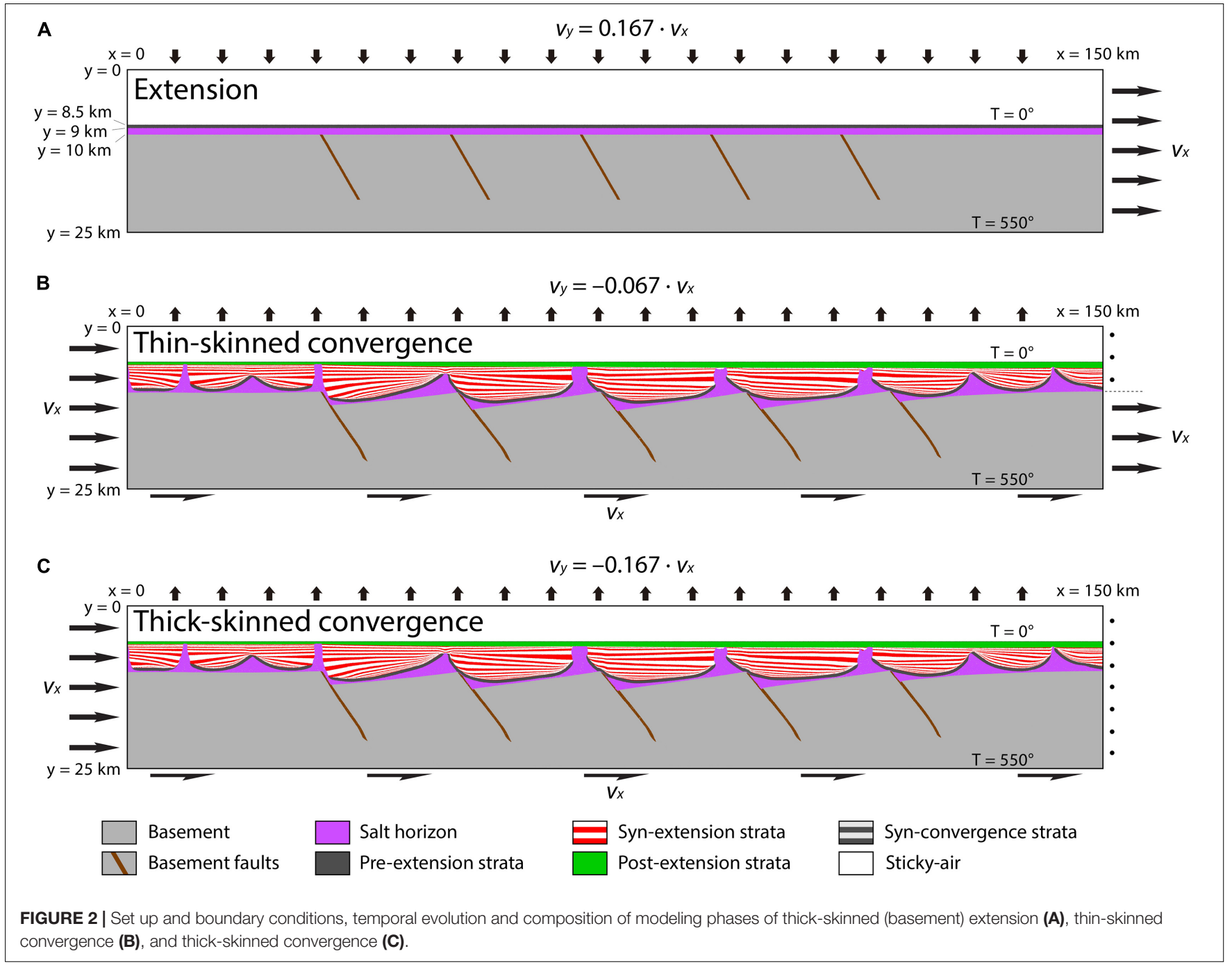

TABLE 1 | Applied material parameters.

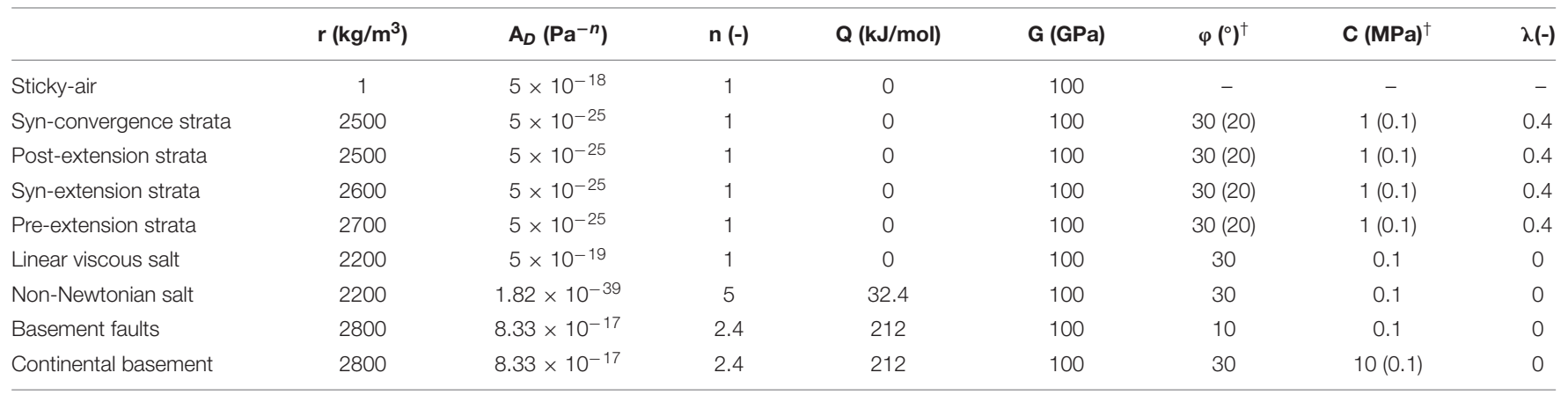

${ }^{\dagger}$ Values in brackets indicate strain weakened value.

\section{Boundary Conditions and Surface Processes}

Presented experiments of tectonic inversion undergo three stages: crustal extension, tectonic quiescence, and thin-skinned or thickskinned (i.e., basement-involved) convergence. Throughout the entire experiments, thermal boundary conditions are free-slip at the model sides and constant temperatures of $0^{\circ}$ and $550^{\circ}$ at the top and the bottom.

\section{Extension}

Extension of the crustal basement and the covering salt and prekinematic layers is implemented by zero horizontal velocity at 
TABLE 2 | Presented numerical experiments.

\begin{tabular}{|c|c|c|c|c|c|}
\hline & Salt & Extension & $\begin{array}{l}\text { Surface } \\
\text { diffusion } \\
\text { during } \\
\text { extension } \\
\left(\mathrm{m}^{2} / \mathrm{s}\right)\end{array}$ & Convergence & Figure \\
\hline Experiment $1 \mathrm{a}$ & Linear & Slow & $10^{-5}$ & Thin-skinned & $3,6,12$ \\
\hline Experiment $1 \mathrm{~b}$ & Linear & Slow & $10^{-5}$ & Thick-skinned & $3,7,12$ \\
\hline Experiment $1 \mathrm{c}$ & Linear & Slow & $10^{-5}$ & $\begin{array}{c}\text { Thin-/thick- } \\
\text { skinned }\end{array}$ & $3,8,12$ \\
\hline Experiment $2 \mathrm{a}$ & Linear & Fast & $10^{-5}$ & Thin-skinned & $3,6,12$ \\
\hline Experiment $2 \mathrm{~b}$ & Linear & Fast & $10^{-5}$ & Thick-skinned & $3,7,12$ \\
\hline Experiment 2c & Linear & Fast & $10^{-5}$ & $\begin{array}{c}\text { Thin-/thick- } \\
\text { skinned }\end{array}$ & $3,8,12$ \\
\hline Experiment $3 a$ & $\begin{array}{c}\text { Non- } \\
\text { Newtonian }\end{array}$ & Slow & $10^{-5}$ & Thin-skinned & $5,9,12$ \\
\hline Experiment 3b & $\begin{array}{c}\text { Non- } \\
\text { Newtonian }\end{array}$ & Slow & $10^{-5}$ & Thick-skinned & $5,10,12$ \\
\hline Experiment 3c & $\begin{array}{c}\text { Non- } \\
\text { Newtonian }\end{array}$ & Slow & $10^{-5}$ & $\begin{array}{c}\text { Thin-/thick- } \\
\text { skinned }\end{array}$ & $5,11,12$ \\
\hline Experiment 4 & $\begin{array}{c}\text { Non- } \\
\text { Newtonian }\end{array}$ & Fast & $10^{-5}$ & - & 5 \\
\hline Experiment 5 & Linear & Slow & $5 \times 10^{-5}$ & - & $\mathrm{S} 1$ \\
\hline Experiment 6 & Linear & Slow & $2.5 \times 10^{-5}$ & - & S2 \\
\hline Experiment 7 & Linear & Slow & $1.25 \times 10^{-5}$ & - & S3 \\
\hline
\end{tabular}

the left boundary and a horizontal velocity of $\mathrm{v}_{x}$ at the right boundary (Figure 2A), with $\mathrm{v}_{x}=1 \mathrm{~mm} / \mathrm{yr}$ (slow extension) or $\mathrm{v}_{x}=8 \mathrm{~mm} / \mathrm{yr}$ (fast extension). At the top, a vertical velocity $\mathrm{v}_{y}=1 / 6 \times \mathrm{v}_{x}$ assures conservation of mass within the Eulerian model domain, while the bottom boundary has zero vertical velocity. All boundary-parallel velocities follow free-slip, i.e., zero shear stress conditions. Velocity conditions apply until reaching a horizontal extension of $10 \mathrm{~km}$, which means $10 \mathrm{Myr}$ for slow extension and 1.25 Myr for fast extension. Surface processes are mimicked by diffusion of the rock-air interface:

$$
\frac{\partial h_{s}}{\partial t}=\kappa \frac{\partial^{2} h_{s}}{\partial x_{i}^{2}}
$$

where $\kappa$ is the diffusion constant, $h_{s}$ is the vertical component of the surface, and $\mathrm{x}_{i}$ the spatial coordinates. If the diffused line is below the previous rock-air interface, erosion applies by converting rock markers to sticky-air markers. If the diffused line is above the rock-air interface, sedimentation occurs by converting sticky-air markers to new sediment markers. Different coefficients for surface diffusion have been applied (Table 2; $\kappa=1.25 \times 10^{-6}, 2.5 \times 10^{-6}, 5 \times 10^{-6}$, and $10^{-5} \mathrm{~m} / \mathrm{s}^{2}$ ) to test their effect on the structural evolution of syn-sedimentary strata during extension and sediment markers alter every 0.5 Myr resulting in a visible strata pattern without any change in material properties (Figures $\mathbf{2 B}, \mathbf{C}$ ). We decided to vary the extension velocity rather then surface processes and salt viscosity, as both those parameters include time and both will be affected by extension velocity that is also dependent on time.

\section{Tectonic Quiescence}

After $10 \mathrm{~km}$ of extension, a phase of tectonic quiescence takes place where all cross-boundary velocities are set to zero and all boundary-parallel velocities remain at free-slip conditions. The diffusion constant describing the surface processes remains constant (equal to extension) during tectonic quiescence. The tectonically quiet phase lasts $0.5 \mathrm{Myr}$ in case of previous slow extension ( $1 \mathrm{~mm} / \mathrm{yr}$ ) but $4 \mathrm{Myr}$ in case of previous fast extension $(8 \mathrm{~mm} / \mathrm{yr})$, to allow mechanical equilibration of the mobile salt and overlying strata. At the end of the tectonically quiet phase, at 10.5 Myr for slow extension and 5.25 Myr for fast extension, a layer of post-extension strata is introduced that covers the previous syn-kinematic layers (Figures 2B,C). The updated rockair interface is horizontal and its vertical position is defined in a way that the thickness of these post-extension strata (green in Figure 2) ranges between 500 and $1000 \mathrm{~m}$, depending on the previous shape of the dynamic surface. Since $\kappa$ is time dependent, differences in post-extension strata thickness take place also due to any diapirism since it defines the highest points and therefore the surface diffusion.

\section{Convergence}

Convergence is induced by applying a horizontal velocity of $\mathrm{v}_{x}=10 \mathrm{~mm} / \mathrm{yr}$ at the left boundary of the model domain (Figures 2B,C). Three difference scenarios are investigated: thinskinned, thick-skinned, and thin- to thick-skinned convergence. Thin-skinned convergence indicates that the basement is not actively shortened and that the sedimentary cover sequence is scraped off along a mechanically weak décollement. In the presented experiments, this décollement occurs within the mobile salt layer. Therefore, thin-skinned convergence is imposed by zero velocity for the top $10 \mathrm{~km}$ of the right boundary and a horizontal velocity $\mathrm{v}_{x}=10 \mathrm{~mm} / \mathrm{yr}$ for the lower $15 \mathrm{~km}$, restricting shortening to take place within the basement (Figure 2B). In case of thick-skinned convergence, the entire right boundary is prescribed as a zero-slip velocity condition, resulting in basement-involved shortening (Figure 2C). In both cases, the bottom boundary condition exhibits zero vertical velocity and a horizontal velocity of $\mathrm{v}_{x}=10 \mathrm{~mm} / \mathrm{yr}$. The top boundary exhibits a negative vertical velocity of $\mathrm{v}_{y}=1 / 15 \times \mathrm{v}_{x}$ and $\mathrm{v}_{y}=1 / 6 \times \mathrm{v}_{x}$ for thin-skinned and thick-skinned convergence, respectively, that accounts for the new material entering the model domain along the left side (Figures 2B,C). Convergence is applied for duration of $5 \mathrm{Myr}$ in case of purely thin-skinned deformation and 3 Myr for thick-skinned deformation. For experiments with variable style of deformation, $3 \mathrm{Myr}$ of thin-skinned deformation are followed by $1.5 \mathrm{Myr}$ of thick-skinned deformation. The diffusion constant during convergence is $\kappa=10^{-6} \mathrm{~m} / \mathrm{s}^{2}$ and sediment markers alter every 0.5 Myr resulting in a visible strata pattern without any change in material properties.

\section{Limitations of the Modeling Approach}

One of the major drawbacks of the modeling approach is the rheology of the salt horizon. As mentioned above, two fundamental types of salt response to stress have been proposed largely based on experimental research: linear viscous and 
temperature-dependent non-Newtonian. The rheology of rock salt during long-term deformation in nature is still controversial (Li et al., 2012), and in fact, rather than exclusive monomineralic halite (i.e., $\mathrm{NaCl}$ ), evaporitic basins are commonly constituted by layered evaporitic sequences, which include variable percentages of evaporites, but also and non-evaporite rocks such as shales, carbonates, sandstones, and others. The relative percentage of each of these rock types will affect the integrated strength profile and its consequent overall rheology. Using a more realistic strength profile is out of the aims of this work, but may be considered for future experiments.

\section{RESULTS}

A total of nine numerical experiments are conducted to test the effects of the rate of extension ( 1 vs. $8 \mathrm{~mm} / \mathrm{yr}$ ), the rheology of the salt horizon (linear vs. non-Newtonian viscosity), and the style of shortening (thin-skinned, thick-skinned, thin- to thickskinned deformation) on the resulting sedimentary architectures and structural styles of inverted basement half-graben systems (Table 2) with a pre-rift salt horizon. First, results of four crustal extension experiments dependent on the rate of extension and salt rheology are presented. Then, each of these four experiments is shortened by the above-mentioned styles of deformation.

\section{Extension and Tectonic Quiescence}

All experiments exhibit a similar deformation pattern of the crustal basement and related faults during extension (Figures 3, 4): strain accumulates along the weak fault zones which leads to a domino-style tilted basement blocks. The central faults tend to exhibit more offset than the lateral ones. After $10 \mathrm{~km}$ of extension, the basement-cover interface represents a system of five half-grabens of $\sim 20 \mathrm{~km}$ width and $2-3 \mathrm{~km}$ depth (Figures 3, 4). However, experiments differ strongly in terms of evolution of the syn-extension strata accumulation and their interaction with the mobile salt horizon.

\section{Linear Salt Viscosity}

After $5 \mathrm{~km}$ of extension, experiment 1 with a linear salt viscosity of $10^{18} \mathrm{~Pa} \cdot \mathrm{s}$ and an extension rate of $\mathrm{v}_{x}=1 \mathrm{~mm} / \mathrm{yr}$ shows a series of open synclines of syn-extension strata covering and lapping the rigid pre-kinematic layer on both limbs (Figure 3A). The synclines exhibit a wavelength of $\sim 20 \mathrm{~km}$ above the halfgrabens and $10-15 \mathrm{~km}$ to the left and right sides of the model domain. The pre-kinematic layer is generally undeformed except above the leftmost normal fault and along the lateral boundaries, where it is broken allowing the salt to reach the surface (Figure 3A). Narrow anticlines between the wider syn-extension basins form initially above the normal faults but migrate onto the footwall of the respective fault during extension. After $7.5 \mathrm{~km}$ extension, some salt anticlines evolved into salt diapirs flanking vertically subsiding minibasins. Other anticlines (e.g., at $x=20 \mathrm{~km}$ ) are covered by newly accumulated undeformed strata (Figure 3A). Accumulated syn-extension strata patterns indicate basins rotation around an horizontal axis, initially synthetic to the basement blocks, but become antithetic after further extension. After $10 \mathrm{~km}$ of extension, up to 6-kmthick sequences of syn-extension strata accumulated into the synclinal structures. Synclines are separated by salt diapirs that either flare to the surface or are shallowly buried by ephemeral roofs of syn-kinematic sediments. An additional $0.5 \mathrm{Myr}$ of tectonic quiescence shows no significant effect as most of the synclines are primary welded and ground to the basement blocks along most of their lengths. Slight internal deformation of the minibasins occurs immediately above the tilted basement fault block after touchdown.

Experiment 2 with an extension rate of $\mathrm{v}_{x}=8 \mathrm{~mm} / \mathrm{yr}$ shows distinctly different patterns of syn-extension strata; broadly speaking the sedimentary infill is more asymmetric than that developed at lower extension rate because depocentres are more coupled with basement in the hanging all of the extensional faults (Figure 3B). After $5 \mathrm{~km}$ of extension, surface subsidence and related deposition of strata is roughly concordant with the deformation of the basement blocks. After $7.5 \mathrm{~km}$ of extension, the left parts of the syn-extension basins undergo further synthetic rotation and salt diapirs extrude directly above the faults' upper tips. After $10 \mathrm{~km}$ of extension, sedimentary strata accumulate in $\sim 10$-km-wide basins situated above fault blocks (Figure 3B). In the right part of the syn-extension basins, subsidence decreases and condensed sequences develop laying on top of the pre-kinematic layer. The leftmost $\sim 30 \mathrm{~km}$ and rightmost $\sim 20 \mathrm{~km}$ do not exhibit significant subsidence. 4 Myr of post-extension tectonic quiescence promotes further subsidence and strata accumulation leading to antithetic rotation of former strata above fault blocks accompanied by salt diapirism, once the initial depocentres became welded or nearly welded. At the sides of the model domain, strata accumulate to form younger -diachronous- basins separated by salt cored anticlines.

The difference in salt mobility for slow and fast extension is shown by the lateral distribution of vertical salt thickness after $5 \mathrm{~km}$ and $10 \mathrm{~km}$ of extension (Figures 4A,B). For experiment 1 with slow extension, the peaks of $\sim 2 \mathrm{~km}$ and $\sim 4 \mathrm{~km}$ after $5 \mathrm{~km}$ and $10 \mathrm{~km}$ of extension, respectively, indicate the salt diapirs flare to the surface, while the initially $1 \mathrm{~km}$ thick salt horizon thins to 100-200 $\mathrm{m}$ below the subsiding basins (Figure 4A). In contrast, during fast extension, inflated salt does not exceed $\sim 1.3 \mathrm{~km}$ of thickness (Figure $4 \mathrm{~B}$ ). In this case, the experiment has not enough time for salt to be fully evacuated as a result of thick-skinned extension; however, since primary welds (or near primary welds) develop close to the basement faults and salt inflates upward along the tilted hanging wall, differential loading by syn-extensional sedimentation favors upwelling of underlying salt. Wider salt diapir pedestals and more gaps by stretching of the pre-kinematic cover form with respect to slow extension. Low values of 200-400 m indicate reduced salt thickness where subsiding basins weld to the footwall of fault blocks (Figure 4B).

Additionally, a series of slow $\left(\mathrm{v}_{x}=1 \mathrm{~mm} / \mathrm{yr}\right)$ extension and linear salt viscosity experiments with slower surface diffusion were conducted due to the time dependence of the diffusion coefficient in contrast to faster extension (Supplementary Figures 1-3). Results show that for $\kappa=5 \times 10^{-6} \mathrm{~m} / \mathrm{s}^{2}$, the wavelength of downbuilding minibasins remains dependent on the basement fault distribution (Supplementary Figure 1). 
A further decrease to $\kappa=2.5 \times 10^{-6} \mathrm{~m} / \mathrm{s}^{2}$ results in a shorter wavelength of minibasins in certain grabens, while other graben structures remain filled by large sedimentary synforms (Supplementary Figure 2). A surface coefficient of $\kappa=1.25 \times 10^{-6} \mathrm{~m} / \mathrm{s}^{2}$ implies a similar bulk mass movement as for the fast extension experiment with $\mathrm{v}_{x}=8 \mathrm{~mm} / \mathrm{yr}$ leads to the development of minibasins with a wavelength of $\sim 5-7 \mathrm{~km}$ and salt walls are generally absent (Supplementary Figure 3).
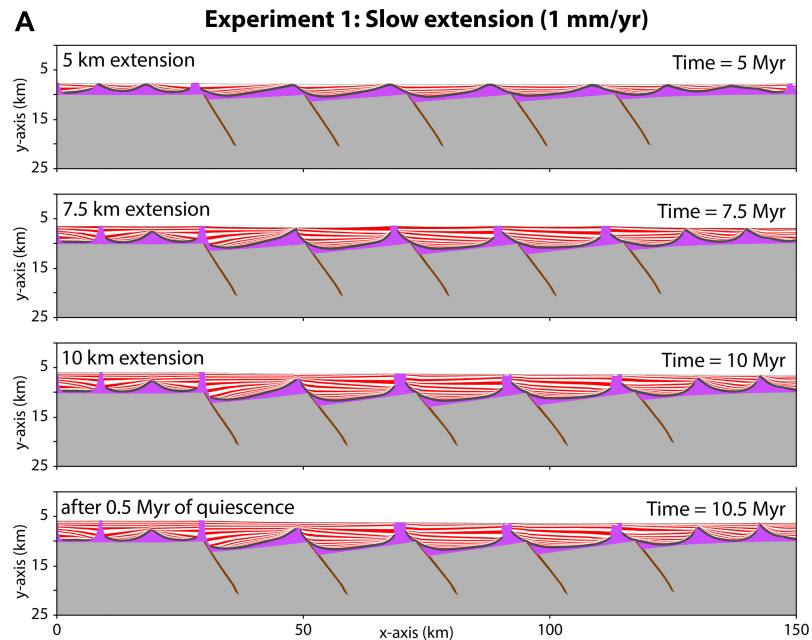
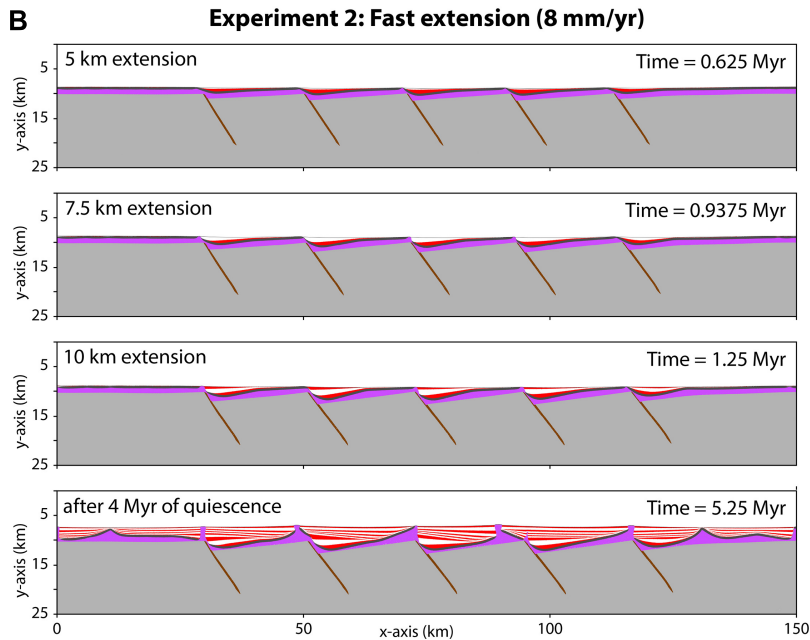

FIGURE 3 | Marker composition of thick-skinned extension and tectonic quiescence with a linear viscous salt rheology. (A) Extension rate $=1 \mathrm{~mm} / \mathrm{yr}$. (B) Extension rate $=8 \mathrm{~mm} / \mathrm{yr}$. See Figure 2 for color code.
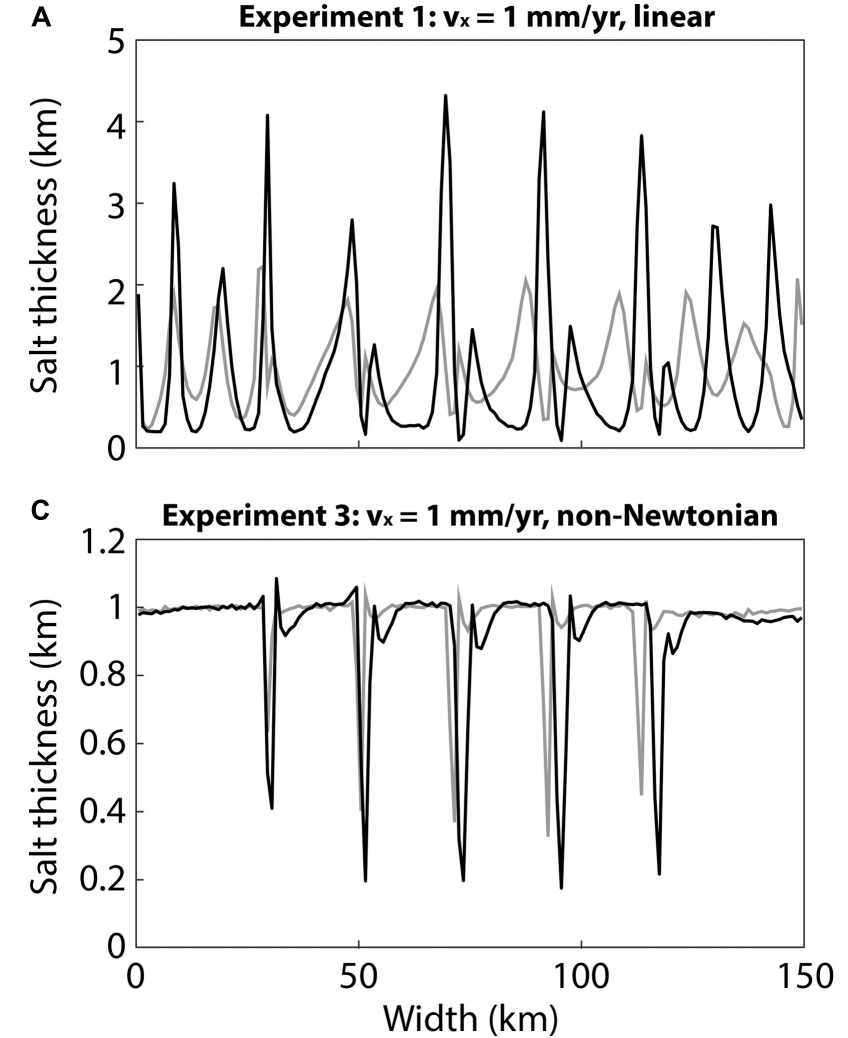

B

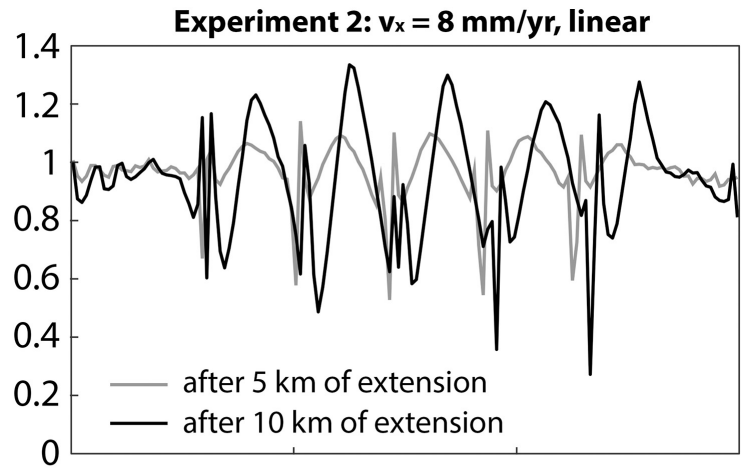

D

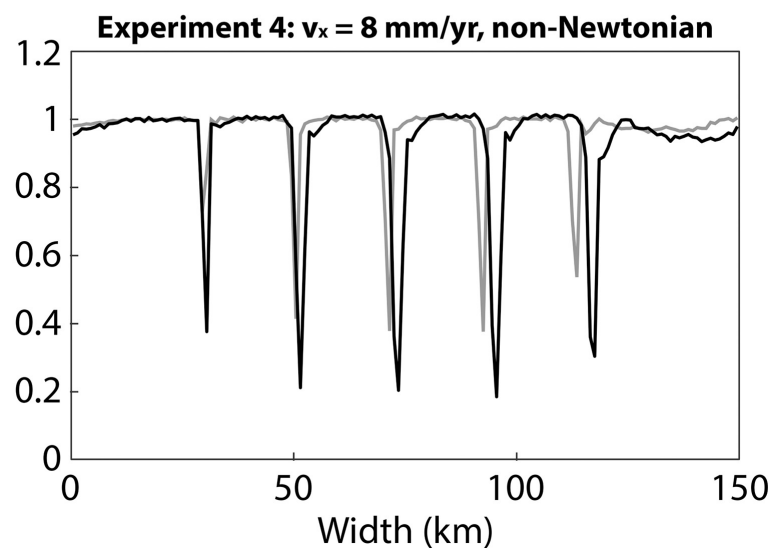

FIGURE 4 | Thickness of salt after $5 \mathrm{~km}(50 \%)$ and $10 \mathrm{~km}$ (100\%) of extension. (A) Extension rate $=1 \mathrm{~mm} / \mathrm{yr}$, linear salt viscosity. (B) Extension rate $=8 \mathrm{~mm} / \mathrm{yr}$, linear salt viscosity. (C) Extension rate $=1 \mathrm{~mm} / \mathrm{yr}$, non-Newtonian salt viscosity. (D) Extension rate $=8 \mathrm{~mm} / \mathrm{yr}$, non-Newtonian salt viscosity. 


\section{A Experiment 3: Slow extension $(1 \mathrm{~mm} / \mathrm{yr})$}

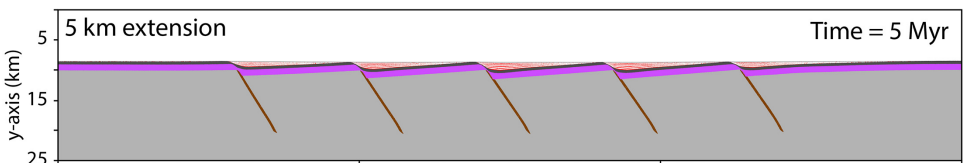

$5.7 .5 \mathrm{~km}$ extension
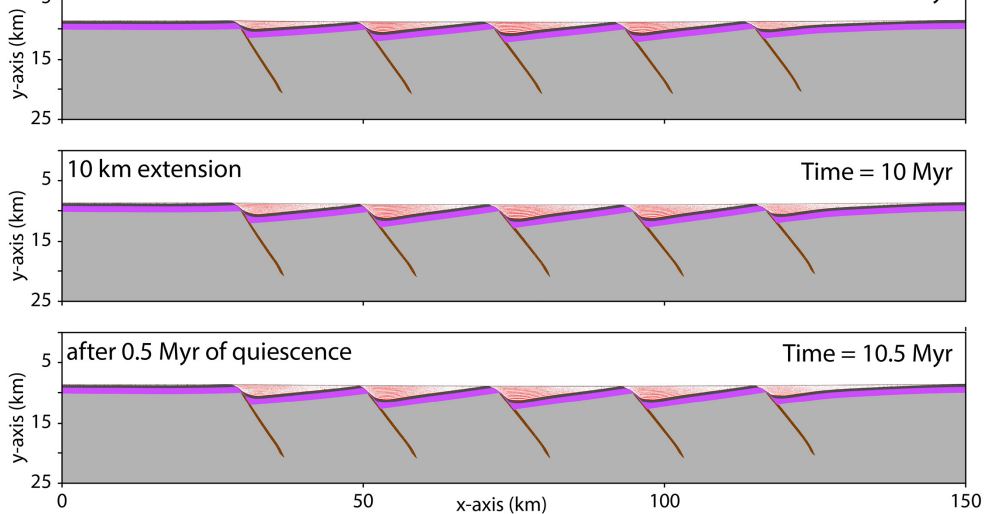
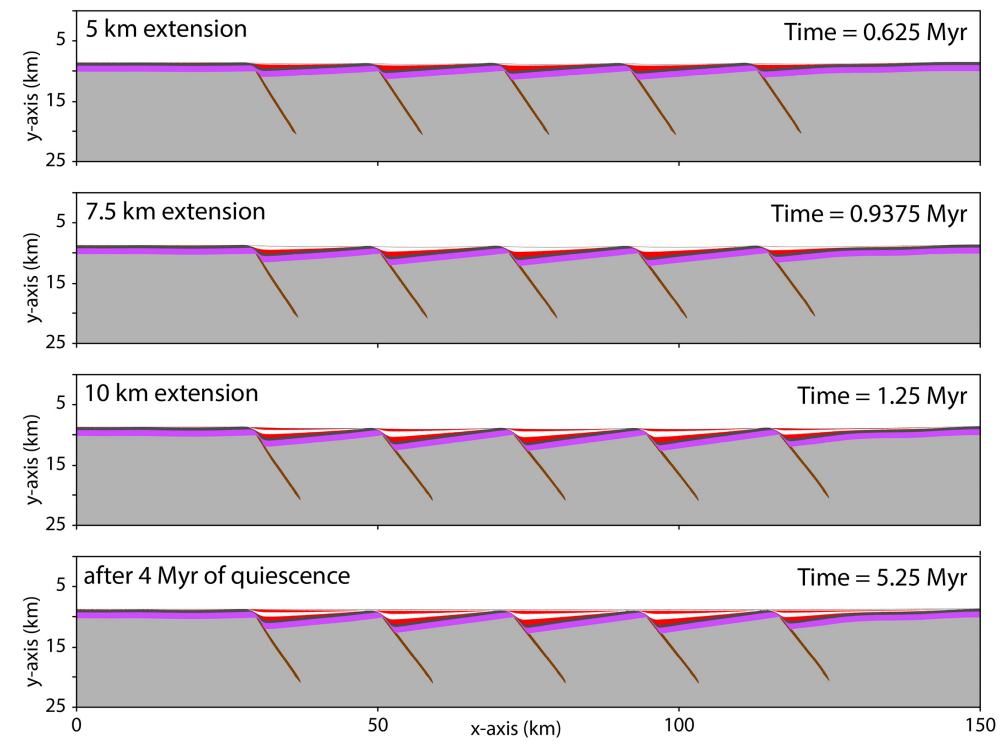

FIGURE $\mathbf{5}$ | Marker composition of thick-skinned extension and tectonic quiescence with a non-Newtonian viscous salt rheology. (A) Extension rate $=1 \mathrm{~mm} / \mathrm{yr}$. (B) Extension rate $=8 \mathrm{~mm} / \mathrm{yr}$. See Figure $\mathbf{2}$ for color code. 


\section{Non-Newtonian Salt Viscosity}

After $5 \mathrm{~km}$ of extension, experiment 3 with a non-Newtonian salt viscosity and an extension rate of $\mathrm{v}_{x}=1 \mathrm{~mm} / \mathrm{yr}$ shows a series of asymmetric synclines of syn-extension strata (Figure 5A). The pre-kinematic rigid horizon is disrupted by the upward propagation of basement normal faults. Sedimentary wedge patterns develop according to the fault block rotation within the basement, which defines the variable subsidence of the evolving basins. Additional 0.5 Myr of tectonic quiescence does not result in any significant vertical growth of the sedimentary basins (Figure 5A). The geometrical evolution of sedimentary strata developing during experiment 4 with fast extension and non-Newtonian salt rheology resemble its slow counterpart (Figure 5B); the only difference is represented by the number and thickness of syn-extension strata. After $10 \mathrm{~km}$ of extension, the vertical thickness of syn-extension strata depends on the subsidence imposed by the underlying basement fault blocks. A 4-Myr-long phase of tectonic quiescence has no effect on the strata pattern other than $\sim 100 \mathrm{~m}$ of additional sediment deposition covering the fault-related basins (Figure 5B).

The lateral variation of salt thickness after $5 \mathrm{~km}$ and $10 \mathrm{~km}$ extension, respectively, shows a similar pattern, independent of extension rate (Figures 4C,D). In both cases, the general vertical thickness remains at the initial $1 \mathrm{~km}$, with low values at the locations of basement normal faults, where the salt horizon is offset and the syn-extension strata weld against the uppermost tip of the footwall of the normal fault or to the fault scarp in the slow and fast extension experiments, respectively. In general, it must be emphasized how strong the coupling of the supra-salt sequences and basement in the experiments with non-Newtonian salt viscosities are when compared to the largely decoupled system observed for those experiments with linear viscosity salt.

\section{Convergence}

After extension and a phase of tectonic quiescence, extensional basins are inverted by imposing a horizontal convergence with a rate of $\mathrm{v}_{x}=10 \mathrm{~mm} / \mathrm{yr}$ (Figures $2 \mathrm{~B}, \mathrm{C}$ ). Experiments 1 and 2 with linear salt viscosity are both tectonically inverted by thin-skinned, thick-skinned, and thin- to thick-skinned convergence styles (Table 2; experiments $1 \mathrm{a}, \mathrm{b}, \mathrm{c}$ and $2 \mathrm{a}, \mathrm{b}, \mathrm{c}$ ). For non-Newtonian salt rheology, only experiment 3 (slow extension, Figure $\mathbf{5 A}$ ) is inverted by the different convergence styles (Table 2; experiments $3 \mathrm{a}, \mathrm{b}, \mathrm{c}$ ), because an increased extension velocity (experiment 4) results in nearly identical spatial salt distribution and synextension strata patterns (Figure 5).

\section{Linear Salt Viscosity \\ Thin-skinned convergence}

After $10 \mathrm{~km}$ of convergence, the sedimentary cover sequence registered the initiation of shortening at the right boundary of experiment 1a, where the basement is pulled out of the model domain (Figure 6A). Strain localized along pre-existing salt diapirs flanked by syn-extensional strata. These large-strain shear zones are subvertical following the initial attitude of the diapirs (Figure 3A), but they preferentially dip toward the backstop wall as deformation progresses and welds develop, which leads to clockwise rotation and imbrication of syn-extension minibasins.
Toward the foreland, pre-existing salt bodies localized larger strain than at the central segment. After $30 \mathrm{~km}$ of convergence, several extensional basin sequences are stacked on top of each other, with the rightmost having rotated clockwise by $\sim 80^{\circ}$ (Figure 6A); stacking takes place along thrust welds after necked off salt diapirs (i.e., secondary welds). Syn-convergence strata deposits into piggy-back basins on top of rotating syn-extension strata, forming typical sedimentary growth packages wedging forelandward. After $50 \mathrm{~km}$ of convergence, some of the thrust sheets are deformed by backthrusts rooted down where synextension strata welded against basement fault blocks (i.e., at $x=100 \mathrm{~km})$.

Thin-skinned tectonic inversion after fast extension (experiment 2a) shows a similar general pattern of deformation with stacking of clockwise rotating syn-extension basins (Figure 6B). However, differences in the structural evolution occur due to variable patterns and ages of earlier syn-extension strata, gaps in the pre-kinematic layer, and the presence of narrow basins flanked by diapirs. Diapiric structures are also reactivated, leading to smaller thrust sheets that eventually become internally deformed in between larger thrust sheets $(x=100 \mathrm{~km}$ at $10 \mathrm{~km}$ of convergence). Conversely to experiment 1a, central salt diapirs localized more strain than those at the foreland. After $50 \mathrm{~km}$ of convergence (10.25 Myr total), previously tectonically reactivated diapiric structures become inactive and get fully buried by syn-convergence strata (Figure 6B; $x=140 \mathrm{~km}$ ).

After $10 \mathrm{~km}$ of convergence, strain rate plots of both experiments $1 \mathrm{a}$ and $2 \mathrm{a}$ show no deformation within the crustal basement, while the salt décollement is activated all along the model but showing higher strain rates close to the backstop wall (Figure 6). Furthermore, salt mobility is observed within the diapiric structures. Strain rates indicate that the activity of the salt horizon as a décollement is affected by the normal faults in the basement, where salt thickness diminished during extension (Figures 4A,B) and furthermore during shortening and tectonic welding of the syn-extensional basins against the footwalls (Figure 6). After $50 \mathrm{~km}$ of convergence, both experiments show localization of strain rate within the basement along pre-existing faults, in particular along the frontal faults at $x=80 \mathrm{~km}$. Strain rates also indicate internal deformation of the syn-extensional basins boundaries as backthrusts nucleate at the apex of necked-off salt diapirs (i.e., see three innermost basins in Figure 6A).

\section{Thick-skinned convergence}

Thick-skinned convergence with linear salt viscosity experiments display more distributed deformation within the cover sequence than thin-skinned convergence experiments (Figure 7). After $10 \mathrm{~km}$ of convergence, experiments are $100 \%$ tectonically inverted (i.e., same amount of extension and convergence). In broad terms, salt diapirs remain subvertical, localize and accommodate horizontal shortening but also account for the vertical offset between bounding syn-extensional minibasins as slip is transferred from the inverted basement faults. This opposites what we observed in thin-skinned convergence experiments where salt diapirs are tilted. Inverted normal faults close to the backstop wall show net shortening, while distal 
A Experiment 1a: Thin-skinned convergence after slow extension
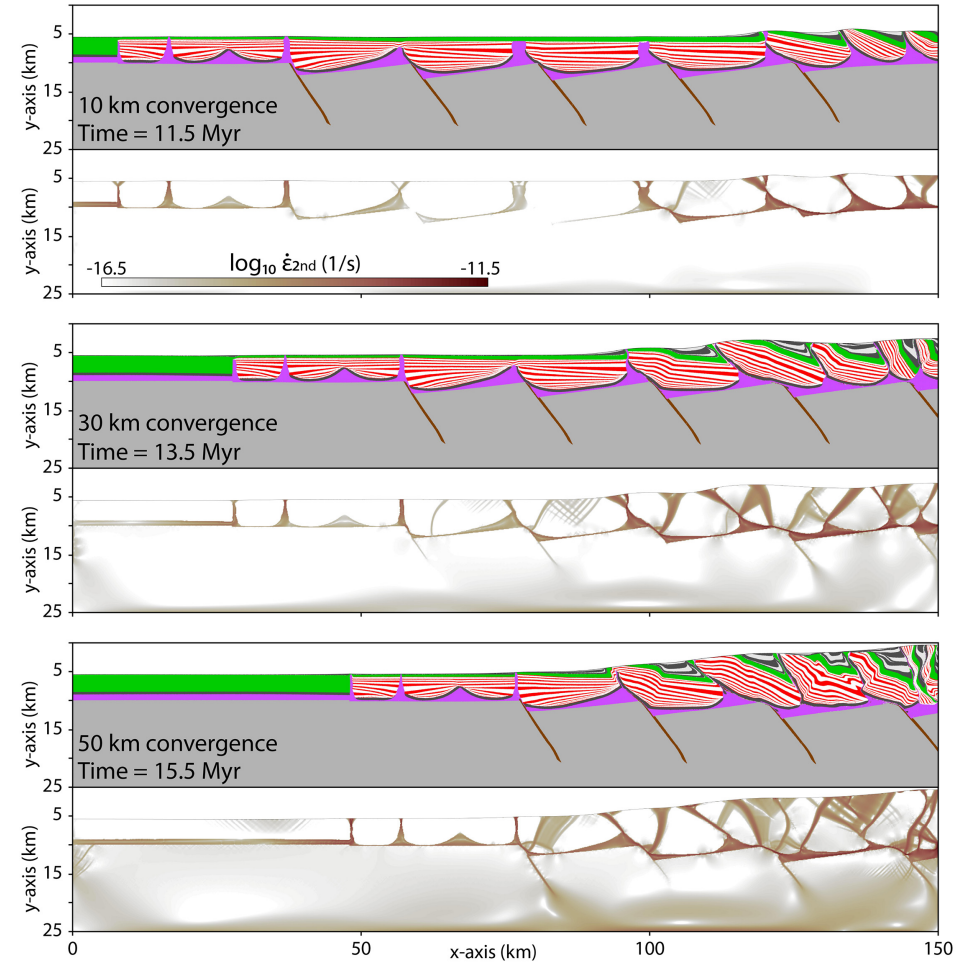

\section{Experiment 2a: Thin-skinned convergence after fast extension}
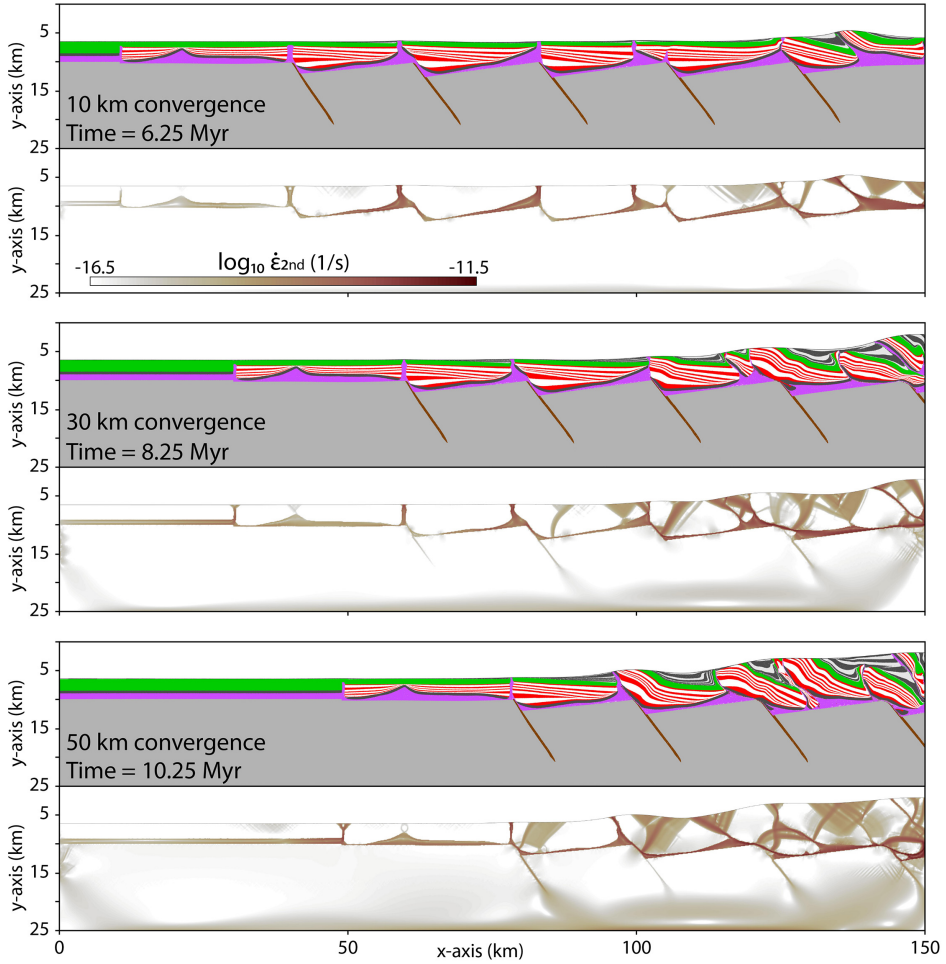

FIGURE 6 | Thin-skinned convergence with linear salt viscosity. (A) After slow extension; (B) After fast extension. Upper diagrams: Marker composition. Lower diagrams: Second invariant of the strain-rate tensor. Strain accommodated by salt squeezing and slip along the basal detachment during early shortening, whereas internal deformation of minibasins mostly takes place afterward and toward the fold-thrust belt hinterland (i.e., right hand side of the experiments). 
faults exhibit net extension. Experiment $1 \mathrm{~b}$ that underwent slow extension shows syn-extensional basins that rotated clockwise together with the basement blocks (Figure 7A). Salt diapiric structures act as large-strain zones accommodating shortening. The diapir closest to the backstop wall $(x=145 \mathrm{~km})$ exhibits the largest amount of syn-convergence offset. Ongoing convergence leads to large offsets along the basement faults. After $30 \mathrm{~km}$ of convergence, the cover sequence is either offset along reactivated diapirs above inverted normal faults $(x=125 \mathrm{~km})$ or internally deformed as a result of basement fault activity beneath $(x=50 \mathrm{~km})$, while the most distal part $(x<50 \mathrm{~km})$ is shortened in a thin-skinned deformation style (Figure 7A).

Thick-skinned convergence of experiment $2 b$ that underwent fast extension accommodates shortening of the cover sequence along salt diapirs until $100 \%$ of inversion (Figure 7B). With ongoing shortening, the cover sequence furthermore deforms where underlying basement faults are active. In contrast to thin-skinned convergence, the surface slope of thick-skinned-shortened experiments remains shallower resulting in more intense distal deformation and more abundant back-thrusting within the cover sequence.

Strain rates illustrate deformation along the basement faults and at the base of the basement, where it is scraped off by the backstop wall at the right side (Figure 7). The change from localized to diffuse strain rates at $y=15 \mathrm{~km}$ indicates the brittleductile boundary within the crustal basement. With ongoing convergence, strain rates within the basement faults slightly decrease, while previously undeformed basement, particularly distal to the backstop, becomes deformed.

\section{Thin- to thick-skinned convergence}

Experiments $1 \mathrm{c}$ and $2 \mathrm{c}$ undergo $3 \mathrm{Myr}$ of thin-skinned convergence ( $30 \mathrm{~km}$ of horizontal shortening), followed by 1.5 Myr (15 km of horizontal shortening) of thick-skinned convergence (Figure 8). Before thick-skinned shortening is activated, syn-extension basins are stacked by thrust welds that localize along former (squeezed out) salt diapirs. After $30 \mathrm{~km}$ of thin-skinned convergence, this stack forms a $\sim 50 \mathrm{~km}$ wide wedge pushed by the backstop wall with a considerably inclined surface slope. The subsequent switch to thick-skinned convergence results in tectonic inversion of basement faults. For both experiments $1 \mathrm{c}$ and $2 \mathrm{c}$, strain is mainly accommodated along basement faults in below and ahead of the thin-skinned wedge, while the faults below the wedge become less inverted (Figure 8). This re-equilibration ultimately leads to a shallower surface slope in contrast to the established one during thinskinned convergence. Strain rates clearly show the activation of deformation within the basement after the switch from thin- to thick-skinned convergence (Figure 8). After a total of $45 \mathrm{~km}$ convergence, new shallow basement thrusts develop away from the inverted normal faults.

\section{Non-Newtonian Salt Viscosity Thin-skinned convergence}

Compared to the experiments with linear salt rheology, experiment 3a with non-Newtonian salt results in a thinner sedimentary cover sequence (Figures 3, 5). Thin-skinned convergence of this relatively thin cover sequence consisting of syn- to post-extension strata leads to imbrication of thrust sheets while the crustal basement leaves the model domain undeformed (Figure 9A). After $10 \mathrm{~km}$ of convergence, deformation initiates at the right boundary, which represents the backstop wall. Above horst structures, the cover sequence is less than $1 \mathrm{~km}$ thick and folding occurs with a respective wavelength. After $30 \mathrm{~km}$ of convergence, a series of thrust sheets emplaced following a piggy-back sequence with a preferred forward vergence associated with syn-convergence growth strata. Thrust spacing is $\sim 10 \mathrm{~km}$ (i.e., about half the crustal basement normal fault spacing and hence half the length of the syn-extensional minibasins) and so. Thrusts were emplaced parallel to the edge of the syn-extensional basins and inactive basement faults, where the cover sequence is thicker and truncate the center of these syn-extensional minibasins (Figure 9A). The frontal thrust is a prolongation of one of the inactive basement faults (Figure 9A). After $50 \mathrm{~km}$ of convergence, the frontal thrust sheet of the previous time step is entirely pushed forward onto the hanging wall of the respective basement fault block and therewith shortened the next syn-extension basin. Each synextension basin is separated into several thrust sheets during thin-skinned shortening.

Strain rates indicate the activation of the salt horizon as a décollement (Figure 9A). In this regard, the nonNewtonian salt becomes mobile only below the actively shortened cover sequence. As such, syn-extension basins are stacked onto each other until the frontal sheet overthrusts the horst, which is when the salt of the next half-graben structure becomes mobilized. Strain rates show very little internal deformation of the basement, which localizes after $50 \mathrm{~km}$ of convergence along the basement normal faults, but internal deformation of the syn-extension basins takes place (Figure 9A).

The viscosity of the salt horizon depends on temperature and strain rate (equation 6). Figure 9B illustrates the vertically averaged viscosity of the non-Newtonian salt horizon after $50 \mathrm{~km}$ of convergence. It shows viscosities as low as $10^{18} \mathrm{~Pa} \cdot \mathrm{s}$ close to the backstop and $10^{21}$ to $10^{22} \mathrm{~Pa} \cdot \mathrm{s}$ for the foreland part $(x=0-70 \mathrm{~km})$ where no shortening localizes within the cover sequence (Figure 9B). Slightly lower viscosities at $x=70-100 \mathrm{~km}$ result from elevated temperatures and increased strain rates below syn-extension strata (Figure 9A). Viscosity values below $10^{18} \mathrm{~Pa} \cdot \mathrm{s}$ furthermore occur where very thin salt inherited from the extensional phase localizes and enhances strain rates when syn-extension strata is thrust over horst structures.

\section{Thick-skinned convergence}

After $10 \mathrm{~km}$ of convergence (i.e., 100\% of tectonic inversion) experiment $3 \mathrm{~b}$ shows that inverted normal faults closer to the backstop wall accommodate more shortening than distal ones (Figure 10A). Deformation in the cover sequence localized where it is thinnest, between the syn-extension basins covering the half-grabens. Ongoing convergence forces the distal synextension basins to thrust over the horst structures after $2 \mathrm{Myr}$. After $30 \mathrm{~km}$ of convergence, the most proximal basement fault $(x=120 \mathrm{~km})$ shows a thrusting-related offset of $\sim 5 \mathrm{~km}$, which 

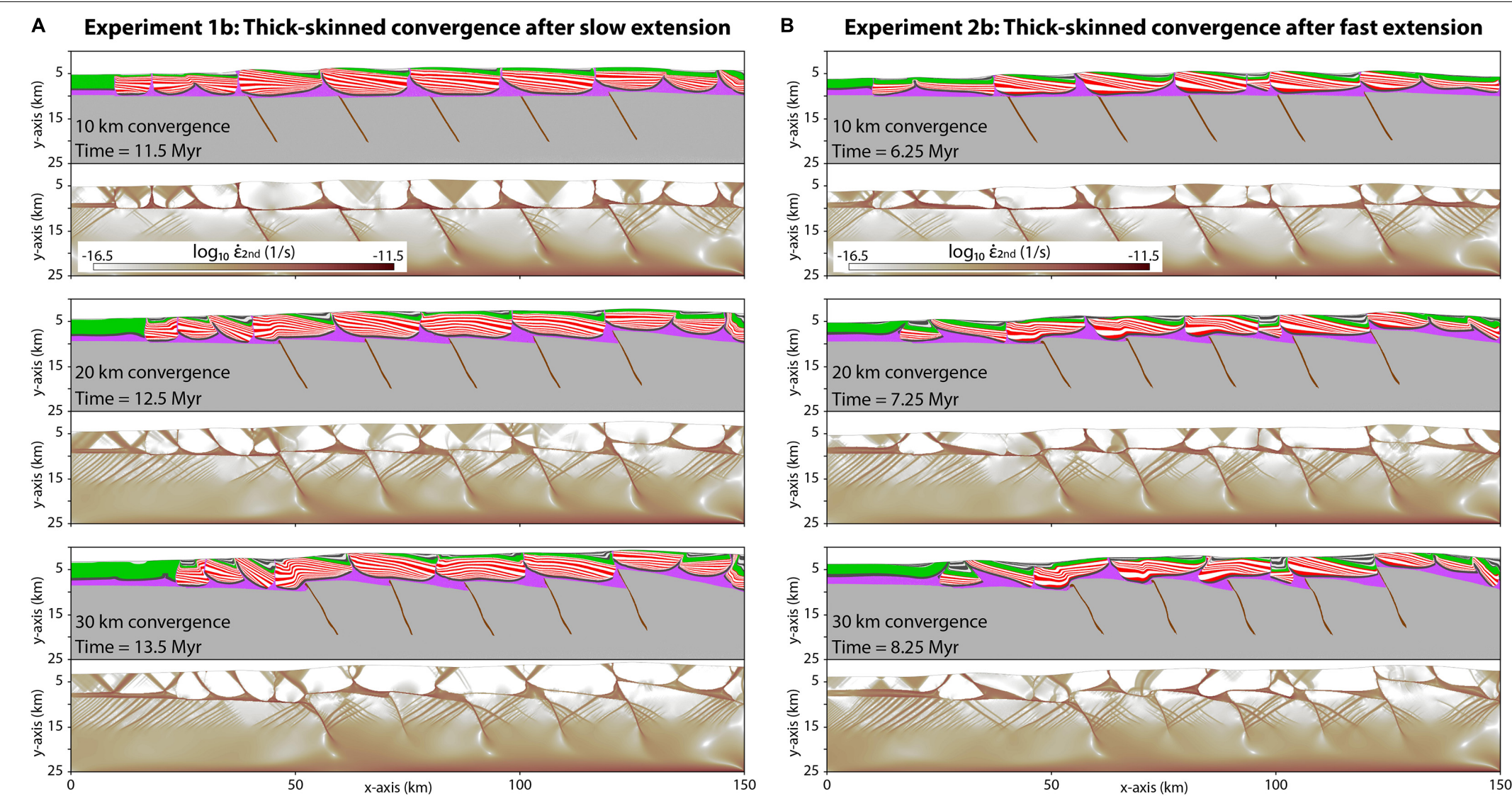

FIGURE 7 | Thick-skinned convergence (> 100\% inversion) with linear salt viscosity (A) After slow extension. (B) After fast extension. Upper diagrams: Marker composition. Lower diagrams: Second invariant of the strain-rate tensor. 
A Experiment 1c: Thin-, thick-skinned conv. after slow extension

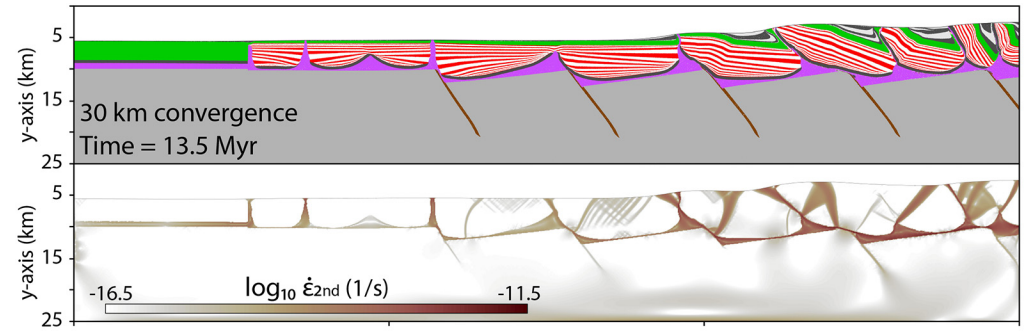

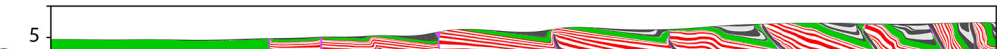

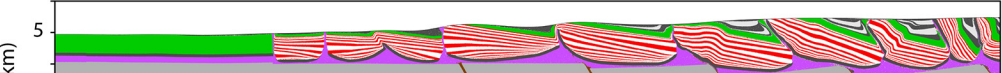

离 $15.37 .5 \mathrm{~km}$ convergence 25 Time $=14.25 \mathrm{Myr}$
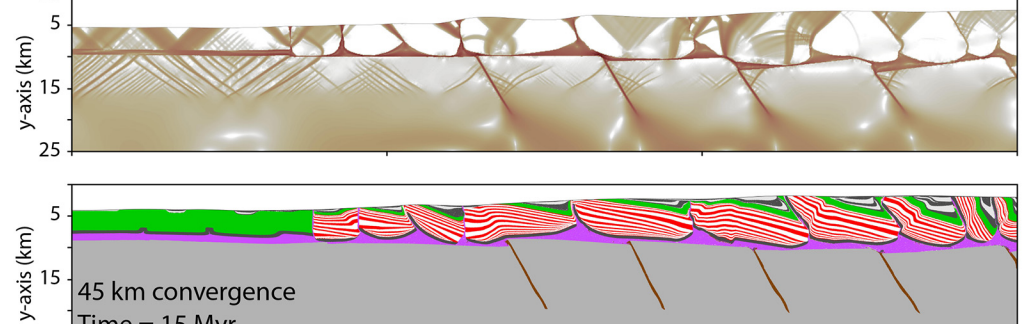

$15 \mathrm{~km}$ convergence

25 Time $=15$ Myr

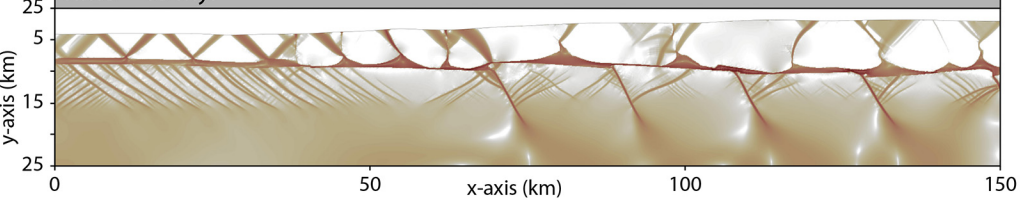

\section{B Experiment 2c: Thin-, thick-skinned conv. after fast extension}
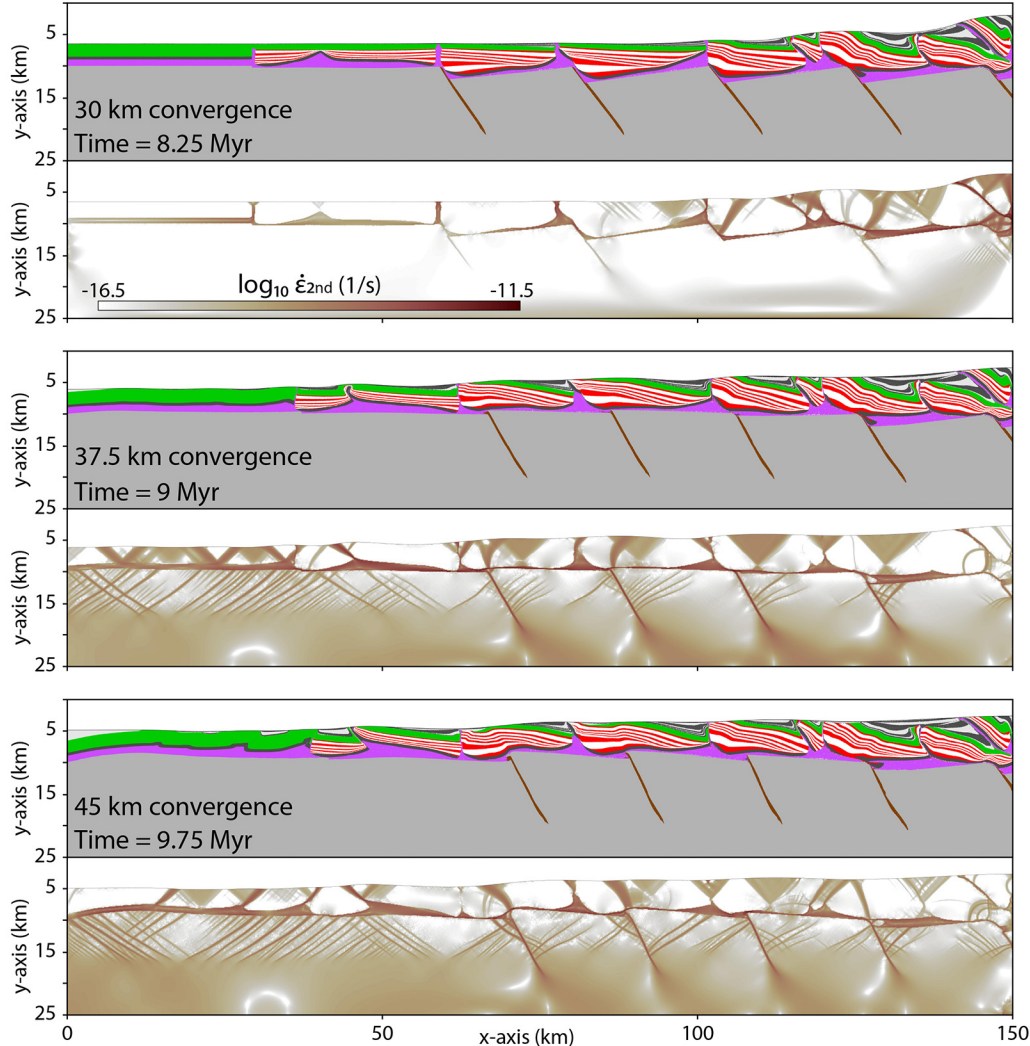

FIGURE $\mathbf{8}$ | Thin- to thick-skinned convergence with linear salt viscosity. (A) After slow extension. (B) After fast extension. Upper diagrams: Marker composition; Lower diagrams: Second invariant of the strain-rate tensor. 

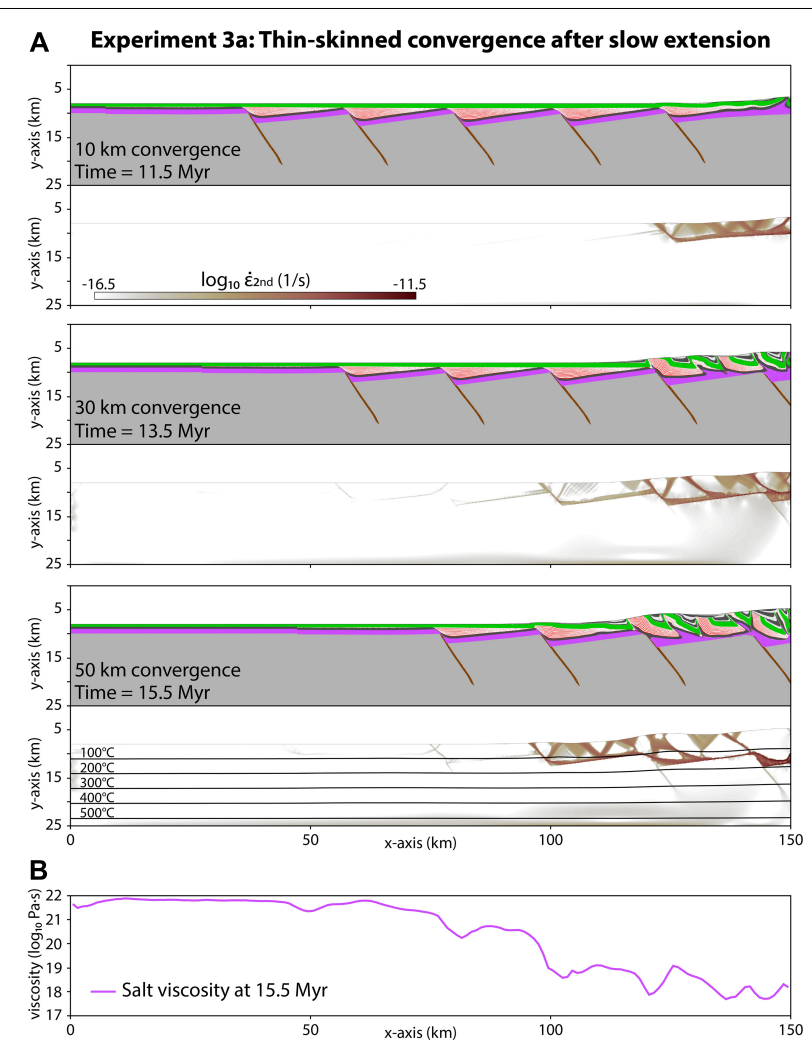

FIGURE 9 | Thin-skinned convergence after slow extension with non-Newtonian salt viscosity. (A) Marker composition and second invariant of the strain rate tensor. (B) Vertically averaged viscosity of the salt horizon at 15.5 Myr. Note the spatial correspondence of the decrease in viscosity and the position of the basement faults. leads to the formation of thick syn-convergence strata on its footwall (Figure 10A). The syn-extension strata that were pushed over the horsts form basement fault-propagation harpoon-like anticlines. Part of the deformation is also transferred ahead of the rifted margin (i.e., left of the model) where the cover is affected by gentle folding.

Strain rates indicate intense deformation within the basement and localization along the inverted normal faults (Figure 10A). The transition from brittle to ductile deformation occurs at $\sim 17 \mathrm{~km}$ depth, below where the strain rate pattern becomes diffuse. Strain rates within the non-Newtonian salt horizon are not significantly increased in comparison to the surrounding rocks, indicating that salt behaves more passively than with a linear rheology, however, still behaves as a décollement between the basement and the cover sequence as shown by the gentle cover folding.

The vertically averaged viscosity of the salt horizon after $30 \mathrm{~km}$ of convergence exhibits similar values between $10^{19}$ and $10^{20} \mathrm{~Pa} \cdot \mathrm{s}$ across the entire model width (Figure 10B). Lower viscosities are only observed below the two frontal anticlines of the cover sequence, where values of $10^{18} \mathrm{~Pa} \cdot \mathrm{s}$ are observed. Values of $>10^{22} \mathrm{~Pa} \cdot \mathrm{s}$ at the very left refer to very low strain rates within the salt where material is entering the model domain (Figure 10B).
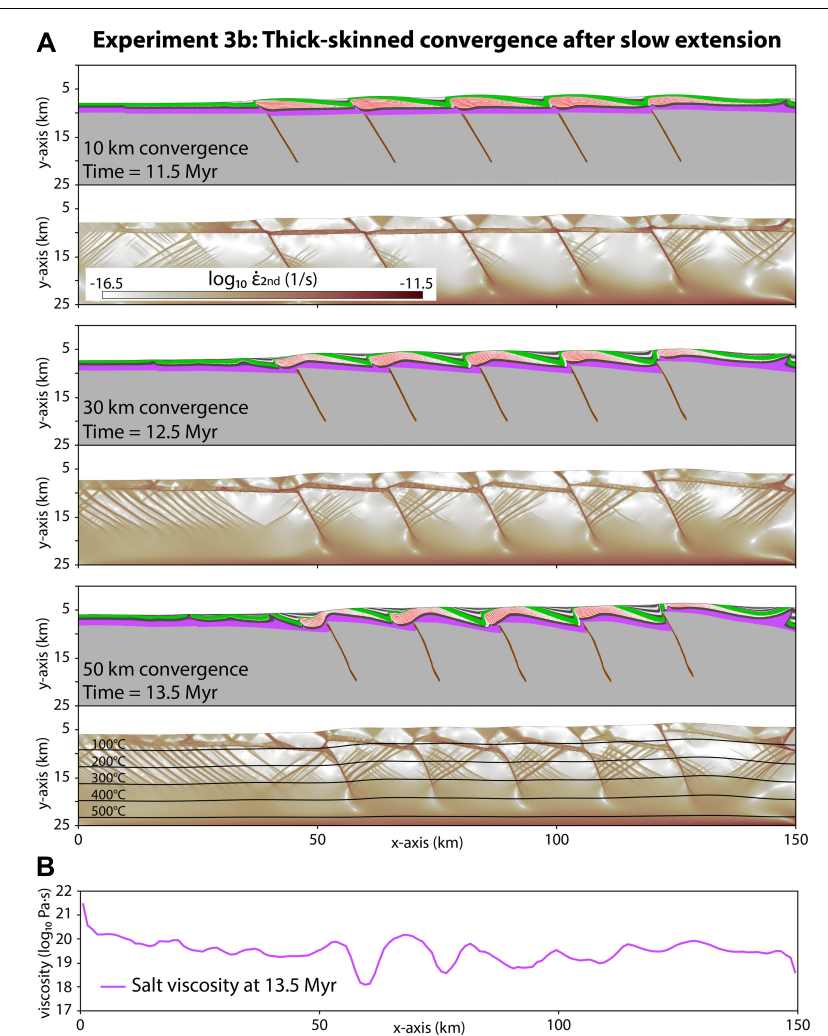

FIGURE 10 | Thick-skinned convergence after slow extension with temperature-activated non-Newtonian salt viscosity. (A) Marker composition and second invariant of the strain rate tensor. (B) Vertically averaged viscosity of the salt horizon at 13.5 Myr. Lowest viscosities are observed below the frontal anticlines. Transition from brittle to ductile deformation occurs where the strain rate pattern becomes diffuse ( $\sim 17 \mathrm{~km}$ depth).

\section{Thin- to thick-skinned convergence}

Experiment $3 \mathrm{c}$ undergoes $3 \mathrm{Myr}$ of thin-skinned convergence (30 $\mathrm{km}$ of horizontal shortening) followed by $1.5 \mathrm{Myr}$ (15 km of horizontal shortening) of thick-skinned convergence (Figure 11A). After $30 \mathrm{~km}$ of thin-skinned convergence, a $\sim 30$ $\mathrm{km}$-wide stack of thrust sheets forms a wedge of the cover sequence at the backstop wall. The wedge's frontal thrust is a propagation of an inactive basement normal fault $(x=120 \mathrm{~km})$. Initiation of thick-skinned deformation results in tectonic inversion of the basement faults. After $37.5 \mathrm{~km}$ of convergence, basement faults proximal to the backstop exhibit less inversion than distal ones (Figure 11A). After $45 \mathrm{~km}$, the proximal wedge of stacked thrust sheets remains unchanged since the change from thin- to thick-skinned convergence. The three frontal normal faults are inverted more than $100 \%$ and force the formation of anticlinal structures in the overlaying syn-extension strata.

Strain rates within the crustal basement illustrate the change from thin- to thick-skinned deformation (Figure 11A). During the latter, strain rates localize along the inverted normal faults and at the base of the basement. After $45 \mathrm{~km}$ of convergence, shallow-dipping thrusts develop in front of the half-graben systems $(x=0-50 \mathrm{~km})$ with a brittle-ductile transition at $\sim 17 \mathrm{~km}$ 


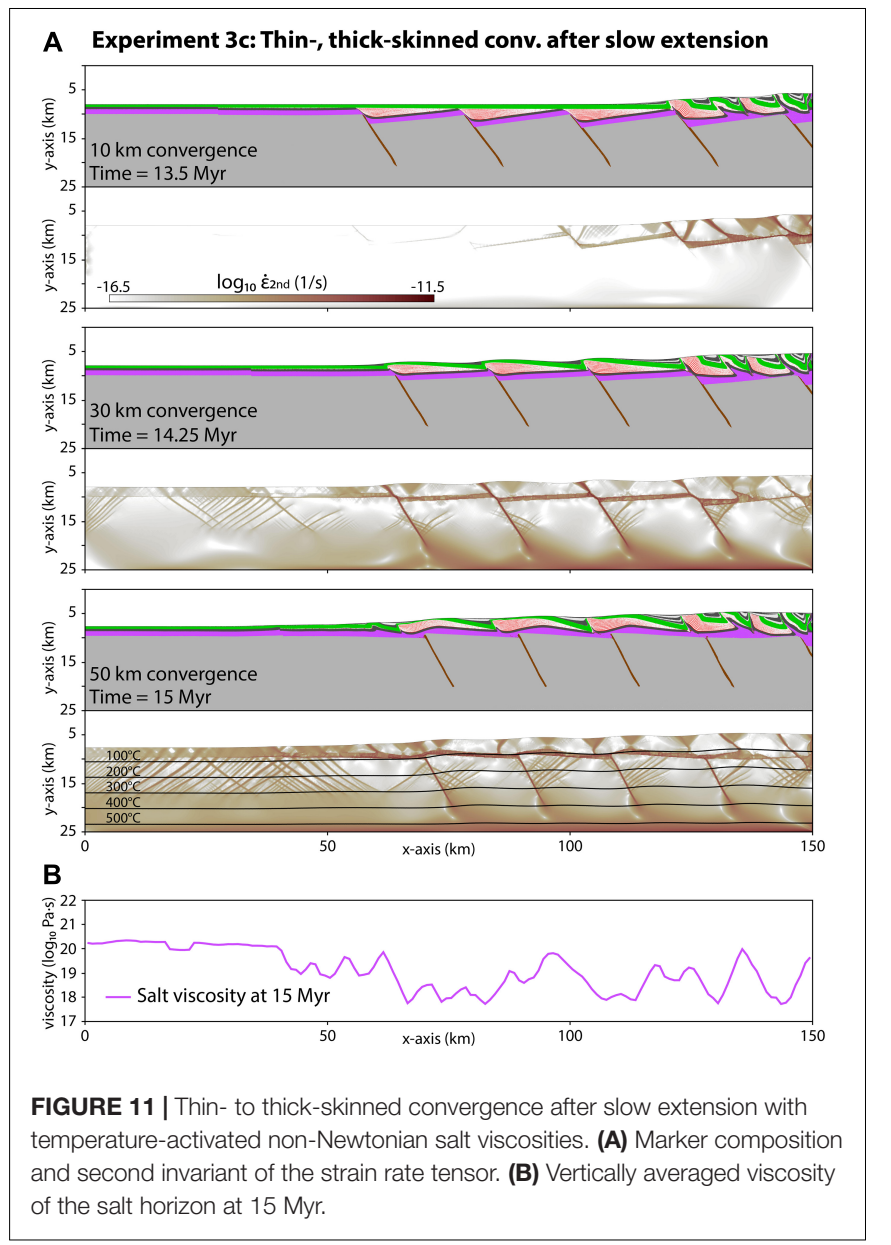

depth. Elevated strain rates indicate salt mobility for thin-skinned deformation and after $45 \mathrm{~km}$ of convergence, when the top of the basement forms a quasi-horizontal geometry (Figure 11A).

After $45 \mathrm{~km}$ of convergence, the viscosities of the salt horizon exhibit values of $\sim 10^{20} \mathrm{~Pa} \cdot \mathrm{s}$ for the frontal part $(x=0$ $40 \mathrm{~km}$ ), where the cover sequence is not shortened significantly (Figure 11B). Between $x=40-150 \mathrm{~km}$, vertically averaged salt viscosities lay between $10^{18}$ and $10^{20} \mathrm{~Pa} \cdot \mathrm{s}$, with the lowest values occurring where the salt horizon is thinned as a result of the inversion along basement normal faults.

\section{DISCUSSION}

Since thrust wedges are commonly constituted by inverted rift basins and telescoped passive margin sedimentary sequences (i.e., the Wilsonian Cycle; see Cohen, 1982), we have simulated the formation and deformation of half-graben basins with an intervening pre-rift salt layer by means of finite difference numerical models. The selected boundary conditions (i.e., extension and subsequent shortening of basins with pre-rift salt) are a widespread scenario for many Alpine fold-and-thrust belts involving Permian and Triassic layered evaporitic sequences, such as in the European Alps, the Pyrenees, the Hellenides or the
Atlas (e.g., Soto et al., 2017). Our results have strong implications as well beyond fold-and-thrust belt scenarios. Extensional results are useful to areas such as the North Sea Rift (e.g., Stewart, 2007), the Portuguese Lusitanian Basin (e.g., Alves et al., 2002) or the Barents Sea Basin (e.g., Rowan and Lindsø, 2017) or many other rift basins with pre-rift salt where limited to negligible shortening followed after extension. In this work, we tested the effects of slow (i.e., $1 \mathrm{~mm} / \mathrm{yr}$ ) and fast (i.e., $8 \mathrm{~mm} / \mathrm{yr}$ ) thick-skinned extension using two contrasting salt rheologies (i.e., linear and temperature-dependent non-Newtonian viscosity) under a given geothermal gradient of $33.3^{\circ} \mathrm{C} / \mathrm{km}$ for the formation of half graben basins. In addition, we have included the transition into a temperature-controlled viscous regime of the modeled tectonic wedges at the accreted basement in the orogenic hinterland below about $15 \mathrm{~km}$ depth. We commence by discussing the results of the extensional phase, and then we continue with those relevant to convergence. Finally, a comparison to natural case studies is provided.

\section{Structural Styles and Basin Architecture}

The results of the presented numerical experiments successfully replicate the archetypal structural styles of rift basins involving a pre-rift salt layer, including half-graben basins and associated sedimentary infill, forced folds promoted by the presence of a decoupling layer, and eventual formation of salt diapirs. A first order control on the size and distribution of extensional basins is imposed by the basement fault spacing, as well as the mechanical properties of the pre-kinematic layer. Slip rate furthermore controls the degree of breaching of the prekinematic layer, with faster rates promoting more faulting, strain and eventually gaps allowing for diapir initiation and minibasin partitioning, and salt extrusion to surface. The presence of such early salt structures has strong implications for the shortening phase, including minibasin rotation and/or stacking, that will be discussed later.

\section{Extensional Phase}

Larger minibasins occur associated with subsiding hanging walls, whereas on either side of the models where only large fault blocks were modeled, smaller and more abundant minibasins developed with flanking salt diapirs or salt anticlines. Minibasin sizes for those domains were controlled by the bending of the pre-kinematic layer in response to sedimentary loading, and thus, relate to its stiffness. Thin-skinned extension and/or erosion affecting the upper hinge of developing monoclines or forced folds triggered reactive diapirism. In addition, differential loading associated with sedimentation focused on the subsiding hanging wall of basement faults favored the expulsion of underlying salt and a fast transition from active to passive diapirism. Halfgraben minibasins developed in linear viscosity salt experiments display an internal stratigraphic architecture controlled by rate of extension along basement faults and related folding of the cover, but also by evacuation of underlying salt. Non-Newtonian salt, on the contrary, suffered no evacuation by differential sedimentary loading or basement fault extension, leading to significantly thinner stratigraphic series. In more detail, for those experiments using linear salt viscosities (Figures 3A,B) 
under slow extension, forced folding of the pre-kinematic cover allowed for the lapping of growth strata on both flanks of the subsiding basins. The basal infill records an initial quasi vertical subsidence therefore, conforming the so-called troughs sensu Rowan and Weimer (1998). Further extension led to breaching of the pre-kinematic layer and diapirism. In a larger picture, the minibasin infill displays from that moment onward a wedgelike geometry (sensu Rowan and Weimer, 1998), however, since salt evacuation processes become recorded at the salt-sediment interface the developed geometries were broadly consistent with tabular halokinetic sequences (e.g., Rowan and Giles, 2012; Roca et al., 2021). The younger sequences, though, are broadly tabular indicating dominant equant vertical subsidence, and conform to the geometries of layers (sensu Rowan and Weimer, 1998). It has to be emphasized how different the degree of coupling between basement and supra-salt cover is depending on the strain rate, as well as the mechanical behavior of the salt layer (i.e., linear viscous vs. temperature dependent non-Newtonian. The lower the strain rate, and the less viscous the salt is the larger the decoupling (compare Figures 3, 5). Experiments with decreased surface diffusion generally lead to shorter minibasin wavelength during extension (Supplementary Figures 1-3); in fact, for decreased surface diffusion, not all minibasins display sizes controlled by the spacing of the underlying fault-blocks.

\section{Convergence Phase}

As pointed out in the introduction, one key aspect controlling the evolution of salt-influenced thrust belts is the presence of early salt structures (Jahani et al., 2007; Granado et al., 2019). Numerical results of extension using linear salt viscosities (i.e., slow and fast) show differences on basin infill geometries but also welding distribution, shape and width of diapir pedestals, and number of salt diapirs and stratigraphic gaps of the prekinematic layer. Such differences are of marked importance to the following shortening stage, controlling the structural styles developed during convergence. In general, salt diapiric structures act as large-strain zones accommodating shortening. In linear viscosity experiments, the salt décollement is activated all along the model, showing higher strain rates close to the backstop wall. Deformation is recorded in the diapirs as far as the foreland, well before thrusting and minibasin imbrication take place. In our models, diapirs are secondary welded and then reactivated as thrust welds. Further shortening leads to imbrication of minibasins, as well as erosion of thrust sheet tips, and sedimentation in piggy back basins. Subhorizontal synorogenic sediments can conceal structurally complicated imbricates bound by earlier, narrower and deep reaching contractional growth wedges (Figures 6A,B). A marked difference exists in thrust angles between thin- and thick-skinned shortening, with the latter being developed at steeper angles; such difference occurs as a result of the differing kinematics: basement-involving thrusts produce more uplift than horizontal translation, since it is resolved by reactivation of steeply dipping basement faults. Since diapiric structures act as large-strain zones these accommodate the vertical movements of the basement steadily. On the contrary, thin-skinned tectonics promotes imbrication of thrusts sheets, and thrust welding at shallower angles. In those experiments with
non-Newtonian salt rheologies significantly thinner stratigraphic series were developed, and this had a profound impact on the wavelength of the contractional structures developed: the thinner the stratigraphic sequences (shallower detachment), the shorter the fold wavelengths developed by buckling. Main anticlines and syn-contractional depocentres were developed by thick-skinned reactivation of basement faults, leading to harpoon-like anticlines and related growth wedges. The applied non-Newtonian temperature-dependent constitutive law for salt translated into flow only being activated by burial below stacked thrust sheets sand related syn-orogenic sedimentation, as well as by increased strain rates at those zones areas nearby basement steps, and the decoupling between basement and cover.

\section{Analysis of Strain Distribution and Salt Behavior}

As outlined above, thick-skinned extension of linear salt experiments resulted in differential loading by syn-extensional sedimentation producing salt evacuation and development of minibasins whose internal architecture is profoundly controlled by the rate of extension (Figure 3 ). This is reflected by the variable thickness of salt during extension (Figures 4A,B). Salt mobilization during slow extension indicates lateral rightward flow above basement blocks that is driven by minibasin subsidence ultimately resulting in the establishment of diapirs (Figure 12A). Diapirs initially develop above basement faults footwalls and early welding of minibasins onto the horst structures permits salt flow across the basement fault zones, further localizing and activating salt diapirism above the footwall. Fast extension with linear salt viscosity results in highly variable subsidence within evolving minibasins and mainly rightward horizontal salt flow toward the horst structures (Figure 12B). However, the horizontal flow is partly driven by the faster subsidence on the hanging wall along the basement faults, which in turn prohibits the subsidence above the footwall to the right. There is no welding of minibasin after full extension, permitting the salt to flow between the graben structures (Figure 12B). After $4 \mathrm{Myr}$ of tectonic quiescence, salt upwelling at diapirs is fed by sedimentary loading until welding of the entire minibasins occurs (Figure 3B). The difference in minibasin geometry and salt flow between slow and fast extension results from the strain rate dependence of viscosity: in detail, faster extension rates produce larger stresses within the viscous salt and therefore increase its resistance to flow.

On the other hand, neither slow nor fast extension and consequent sedimentary loading results in significant evacuation of salt if it follows a non-Newtonian temperature-dependent rheology (Figure 5). Salt distribution across the model remains roughly constant and unchanged from the initial value $(1 \mathrm{~km}$ thickness), except where basement faults cut through and impose localized thinning (Figures 4C,D). Figure 12C illustrates the viscosity within the non-Newtonian salt horizon after $7 \mathrm{Myr}$ of slow extension. The uniform thickness of salt indicates very little variable horizontal flow. Viscosities vary between $10^{20}$ and $10^{22} \mathrm{~Pa} \cdot \mathrm{s}$, which are much larger values than for the linear 


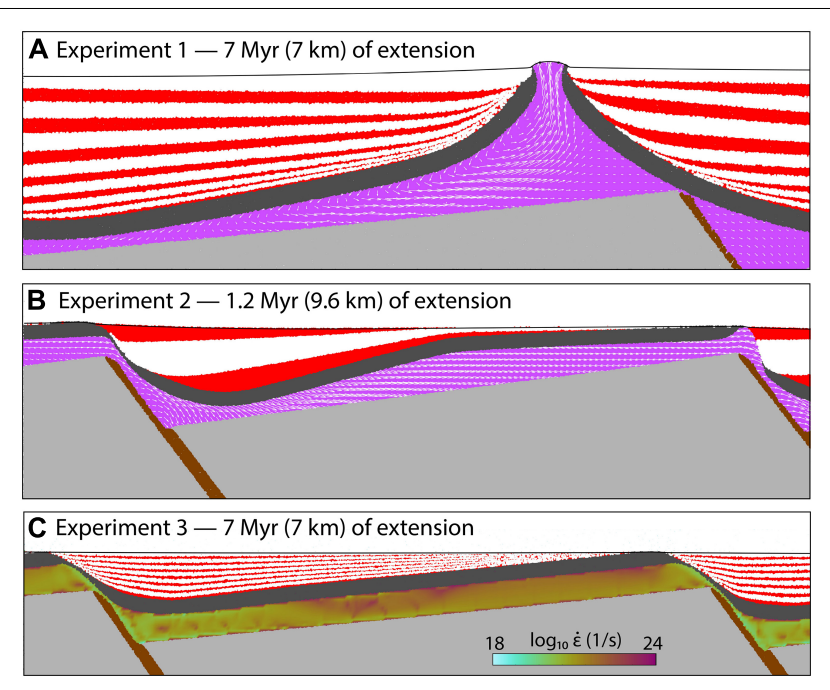

FIGURE 12 | Salt rheological behavior for the extensional phase. (A) Experiment 1 (linear salt viscosity and extension rate $=1 \mathrm{~mm} / \mathrm{yr}$ ) shows loading-induced salt flow along the footwall and passive diapirism. (B) Experiment 2 (linear salt viscosity; extension rate $=8 \mathrm{~mm} / \mathrm{yr}$ ) indicated mainly fault-related minibasin subsidence and minor sub-horizontal salt flow along the footwall. (C) Experiment 3 (non-Newtonian salt viscosity; extension rate $=1 \mathrm{~mm} / \mathrm{yr}$ ) indicates salt viscosities significantly larger than for linear viscous experiments (1018 Pa.s) prohibiting salt flow and minibasin subsidence by salt evacuation. viscous experiments $\left(10^{18} \mathrm{~Pa} \cdot \mathrm{s}\right)$ and overcome the salt viscosity in nature $\left(10^{10}\right.$ and $10^{21} \mathrm{~Pa} \cdot \mathrm{s}$, see Mukherjee et al., 2010 for a review). Viscosities are lower into the graben structure due to the temperature-dependent activation of salt flow. Viscosities of $10^{19} \mathrm{~Pa} \cdot \mathrm{s}$ occur along the basement faults where deformation is localized as a result of the power-law relation between stress and strain rate (Figure 12C).

The non-Newtonian viscosities of salt during the extensional phase prohibit any significant salt flow under the prevailing geothermal gradient (i.e., $33.3^{\circ} \mathrm{C} / \mathrm{km}$; section "Geometrical Setup") and numerical modeling results using linear viscosities of $10^{18} \mathrm{~Pa} \cdot \mathrm{s}$ are in broad agreement with the geometries found for natural case studies of minibasin provinces assisted by thick-skinned extension (e.g., Rowan and Lindsø, 2017). Conversely, the geometries and kinematics and architectural infill formed during the extension phase in the non-Newtonian salt experiments are at odds with natural examples. It is arguable that such differences may arise from our modeling boundary conditions, i.e., the chosen geothermal gradient and the thickness of post-extension strata, which both affect the apparent temperature within the salt horizon, however, in a proximal rift setting such as that modeled here were crustal extension is low, the average geothermal gradient should not be much larger than the used values. In contrast to the extension phase, non-Newtonian salt viscosities during convergence show lower values between $10^{18}$ and $10^{20} \mathrm{~Pa} \cdot \mathrm{s}$ (Figures 9-11). This decrease in viscosity results from temperature increase due to structural and syn-orogenic stratigraphic burial, as well as from localized deformation, i.e., increased strain rates, along the salt horizon decoupling the basement from the overlying sedimentary strata. We also acknowledge that alternative or additional non-Newtonian constitutive laws for the modeled salt processes may be tested and compared to our results to strenghten this line of research.

\section{Comparison to Natural Case Studies}

In the following we compare the results of our numerical modeling with a series of natural examples for which complex structures have been defined as resulting from the contractional reactivation of minibasins; some of which seem to have been clearly initiated by rift tectonics involving thick-skinned extension (e.g., Moroccan Central High Atlas) and some others are still debated. In the first case study -the Moroccan Central High Atlas- there is still some debate as to the degree of decoupling between the presalt basement and its sedimentary cover (i.e., whether the Triassic evaporites represented a thin-skinned detachment or not). The second case study is the Austrian Northern Calcareous Alps fold-and-thrust belt, for which the origin of thick carbonate sequences is debated as to either related to syn-rift thick-skinned extensional faulting (Fernández O. et al., 2020) or post-rift tectonics purely developed by downbuilding and thin-skinned extension on salt (Granado et al., 2019; Strauss et al., 2020).

\section{Central High Atlas Fold Belt, Morocco}

The structure of the Central High Atlas in Morocco (Figure 13A) is interpreted as the result of the Cenozoic tectonic inversion of the Mesozoic Atlas rift basin (e.g., Frizon de Lamotte et al., 2000, 2008 and references therein) resulting from the convergence between the African Plate and the Iberian and Eurasian Plates (Mattauer et al., 1977; Gomez et al., 2000). In the Central High Atlas, the Variscan basement is topped by Permian red beds and Triassic evaporites, siliciclastic rocks and basalts which are overlaid by more than $5 \mathrm{~km}$ of Lower to Middle Jurassic rocks (Baudon et al., 2009). Upper Jurassic and Cretaceous outcrops are scarce and restricted to the margins of the basin. There is still an open debate on the structural evolution of the Central High Atlas regarding if Triassic rocks represent or not an efficient décollement horizon. In the first case displayed (Figure 13B), there is not structural decoupling and the architecture of the chain resulted from the inversion of extensional fault and by coupled buckling of both basement and Mesozoic cover (Poisson et al., 1998; Benammi et al., 2001; Teixell et al., 2003; Arboleya et al., 2004). Thin-skinned tectonics is restricted to the basinal margins where most of the shortening is accommodated (Beauchamp et al., 1999; Benammi et al., 2001; Teixell et al., 2003; Teson and Teixell, 2008) and most folds resulted from the Cenozoic contraction with very limited, pre-shortening folding and salt tectonics (Laville and Piqué, 1992; Beauchamp et al., 1999; Teixell et al., 2003; Arboleya et al., 2004).

Restoration of the Central High Atlas to its pre-contractional stage (Teixell et al., 2003; Arboleya et al., 2004) resembles experiments 3 and 4 (Figure 5) where a non-Newtonian 


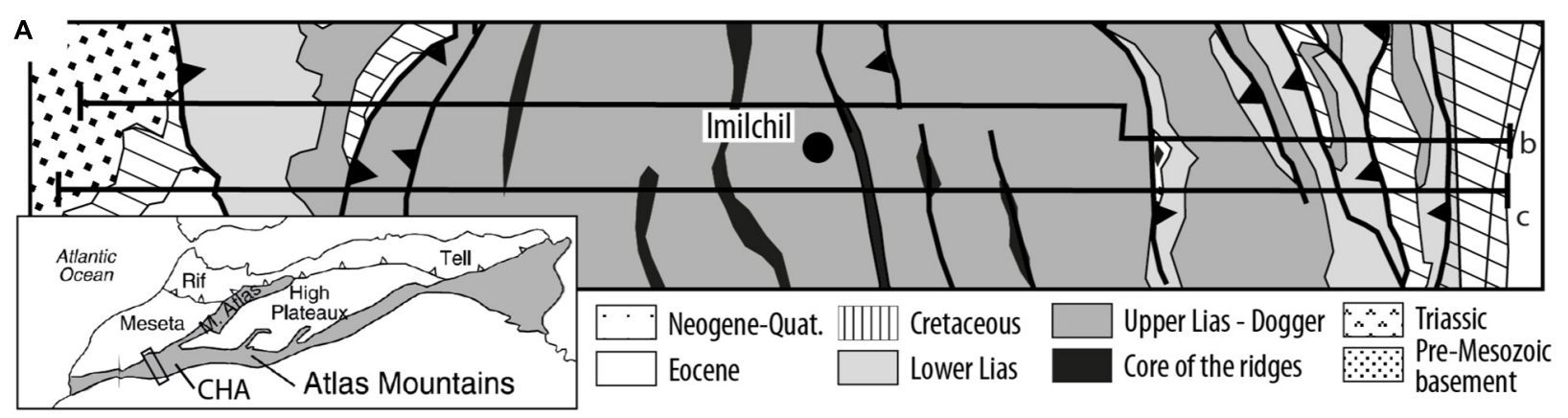

B

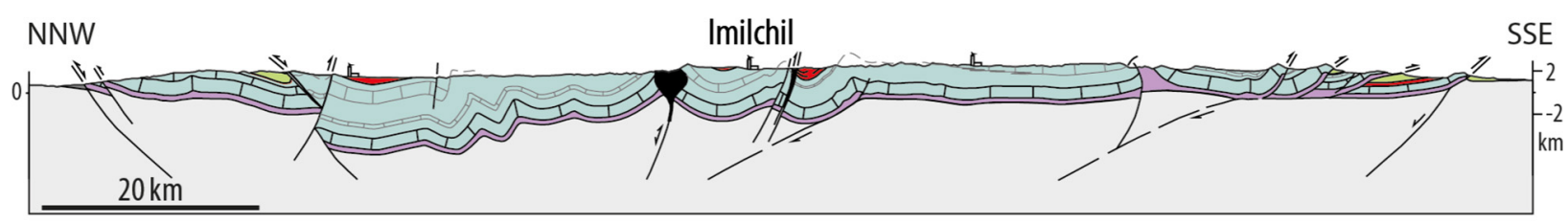

C

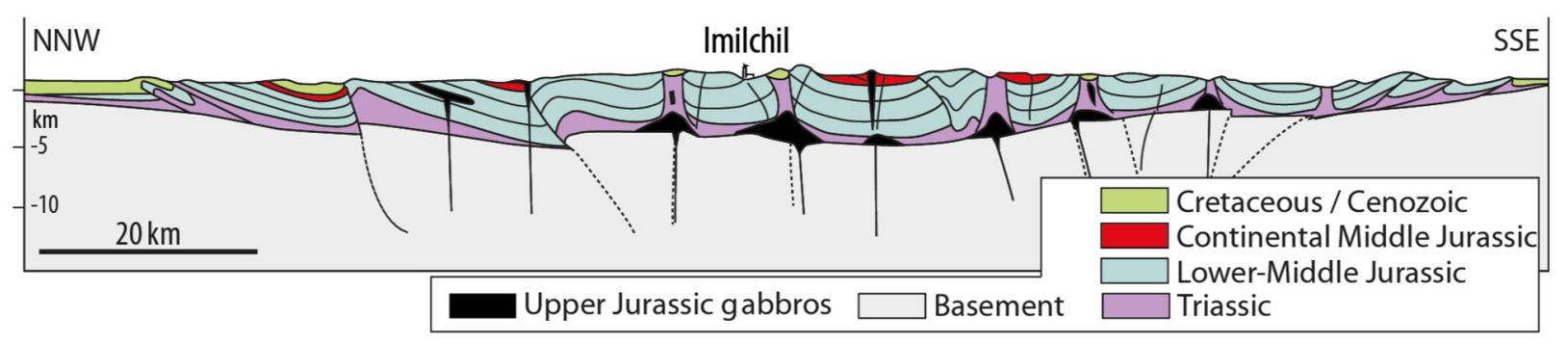

FIGURE 13 | (A) Synthetized geological map of the Central High Atlas (after Teixell et al., 2003; modified). (B) Central High Atlas section from Teixell et al. (2003); (C) Central High Atlas section from Michard et al., 2011 (after Calvín, 2018; modified).

temperature-dependent rheology salt horizon led to a null basement-cover decoupling during the extensional stage (Figure 5). Syn-extensional sedimentation filling directly depends upon the accommodation space created by the extensional offset of steeply dipping normal faults with any influence of salt mobilization either in the models or interpreted in nature. Subsequent shortening led to formation of structural highs dependent upon the degree of inversion of syn-rift normal faults. In the second and opposite interpretation (Figure 13C) and based on integrated structural, paleomagnetic reconstructions and stratigraphic work, the Central High Atlas is thought to represent an extensive diapiric province (Figure 13A) characterized by ENE-WSW trending salt walls with intervening synclinal minibasins that were active during Early and Middle Jurassic times, partly synchronous to rift tectonics and later on rejuvenated during Alpine shortening (e.g., Saura et al., 2014; Martín-Martín et al., 2016; Moragas et al., 2016; Torres-López et al., 2016, 2018; Teixell et al., 2017; Vergés et al., 2017; Calvín et al., 2018). This structural evolution is contingent on the existence of a mobile horizon within the Triassic sequence. Similar boundary conditions and resulting geometries are found in experiments 1 and $1 \mathrm{~b}$ (Figures 3A, 7A, respectively). Both in the Atlas Mountains and these experiments the
Triassic evaporites, in nature, and a linear salt viscosity, experimental décollement allows an efficient basement-cover decoupling and permits salt mobilization and the development of an isolated minibasin province. Structures have been interpreted as squeezed salt walls since some geometries are indicative of halokinetic sequences and because, even if limited, the occurrence of evaporites in the Triassic allows to speculate there was a higher percentage of evaporites than seen in outcrop (Saura et al., 2014). Our numerical models do show the feasibility of such interpretation where early mobilization of salt occurs and where salt can act as an effective décollement during shortening. It is possible, however, that locally abundant gabbro intrusions in the evaporite formation may have contributed to larger viscosities, and to changes in the behavior of the Triassic décollement. Likewise, lateral and vertical changes in the stratigraphy of the layered evaporite sequence may have contributed to rheological variabilities.

\section{Northern Calcareous Alps (NCA)}

The NCA of Austria constitute a $700 \mathrm{~km}$ long E-W striking salt-detached fold-and-thrust belt characterized by thick (up to $\sim 4500 \mathrm{~m}$ ) successions of Neo-Tethyan Triassic passive margin carbonates (Mandl, 2000). The NCA stratigraphy documents 


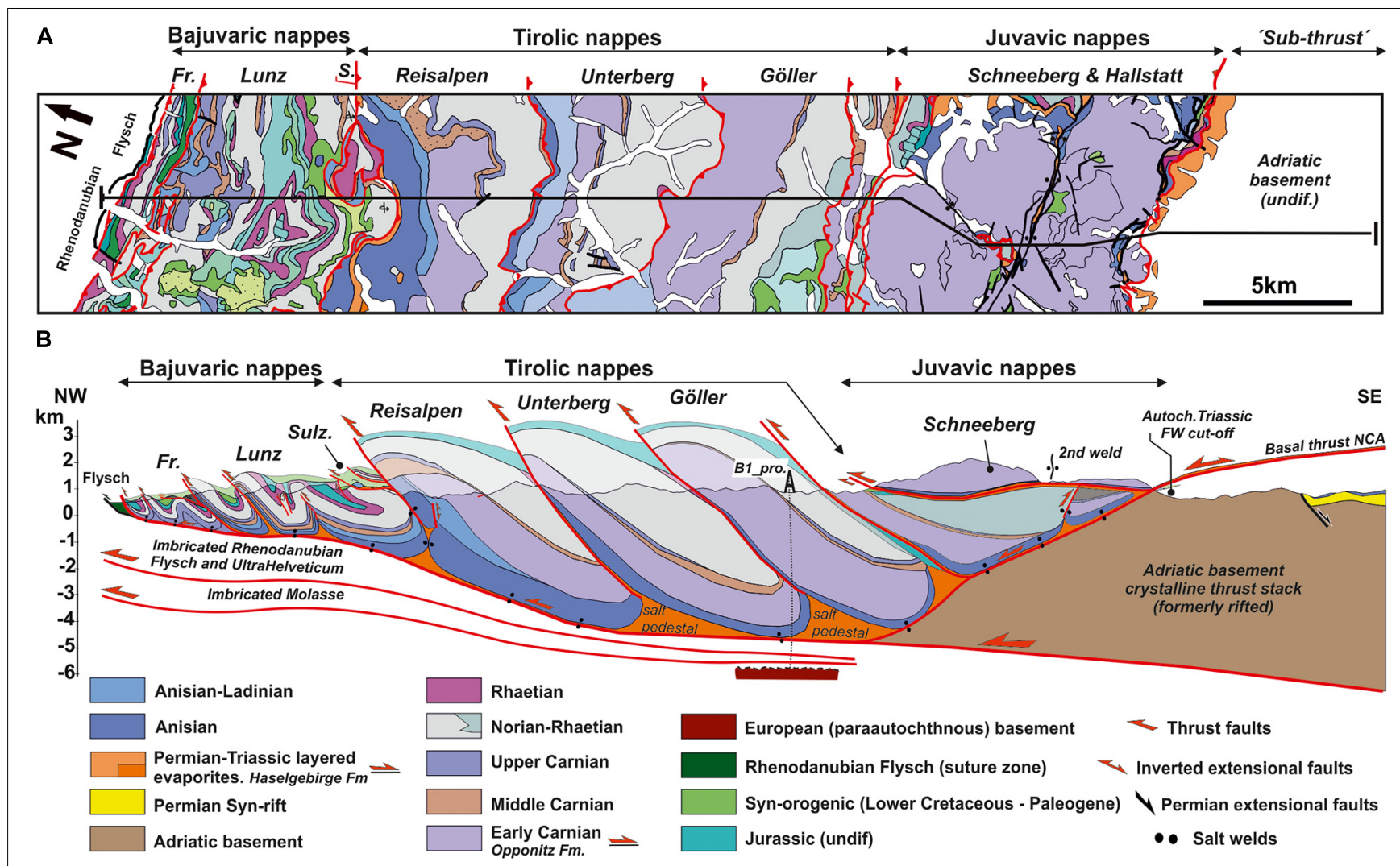

FIGURE 14 | (A) Geological map from the eastern Northern Calcareous Alps around Hohenberg [modified from Schnabel et al. (2002)]. (B) Geological cross-section. B1_pro: Berndorf well protected (25 km east) reached the European crystalline basement at ca. -5600 m, and constrains the NCA basal detachment depth. NCA nappes nomenclature from Mandl (2000). Fr., Frankenfeld nappe; Sulz./S, Sulzberg nappe.

the diachronous growth of Middle Triassic carbonate platforms over a Permian-Triassic layered evaporitic sequence (Strauss et al., 2020) deposited during the late-thinning phase of rifting (Leitner et al., 2017). In the proximal domain of the NeoTethys passive margin, the salt likely constituted an extensive layer overlaying those basement faults responsible for crustal extension, whereas toward the developing ocean, the salt may have been bound by active extensional faults accounting for salt thickness variations. The role of such faults in controlling the accommodation space of the carbonate platforms is still a matter of debate, with some authors proposing salt evacuation and saltdetached extension in a thermally subsiding basin (Granado et al., 2019; Strauss et al., 2020), whereas others still suggest thick-skinned extension (Fernández O. et al., 2020) as the main subsidence and accommodation space driver Considerations on regional geological evidence, facies distribution across the belt, and subsidence analysis indicate a dominating post-rift setting, where accommodation space was provided by thermal subsidence largely assisted by salt evacuation (Strauss et al., 2020). Since Alpine shortening completely sheared off the NCA along the Permian-Triassic evaporites from their pre-salt rifted basement (Linzer et al., 1995), the original relationships between the post-salt stratigraphy and the basement structures responsible for crustal thinning cannot be directly observed.
In this sense, from a exclusively structural point of view, the role of basement faults in the potential formation of the carbonate minibasins may remain elusive. The numerical models presented here aid in further constraining the structural and stratigraphic evolution of the NCA fold-thrust belt. In more detail, Figure 14 shows a new cross-section from the eastern Northern Calcareous Alps in Hohenberg (Lower Austria). The section displays marked changes in depositional stratigraphic thickness and unconformities for the Middle and Upper Triassic carbonate sequences across structurally juxtaposed units which are consistently separated by salt-bearing thrusts. Such differences in stratigraphic development point to a salt behavior akin to that used in the linear salt viscosity experiments. The contractional structural styles are largely controlled by the stratigraphic thickness distribution, with tight folds affecting the thinnest carbonate sequences in the foreland to the north and thrust imbricates involving thicker depocentres in the central parts of the section, as well as the presence of early salt structures. Thrust sheet boundaries occur as thrust welds, and were most likely associated with the position of salt walls formerly flanking the Middle-Late Triassic minibasins. In fact, the imbricated nature of the Tirolic nappes in the section (Figure 14B) suggest that convergence took place along a stepped base salt (purely thin-skinned, or at least with very little basin 
inversion initially). The origin of such stratigraphic thickness changes across salt-bearing thrust could relate to an inherited stepped base salt topography bounding different depositional thickness of salt developed during the late phases of rifting. The northward tilting of the basal NCA thrust and the folding of shallow thrust systems above in the hinterland (i.e., the Juvavic nappes; Figure 14B) relate to the late involvement of the pre-salt rifted basement in the thrust stack (such as in experiments 1c and $2 c$ of thin-skinned followed by thick-skinned convergence; Figure 8), like in many other salt-detached fold-and-thrust belts worldwide (Tavani et al., 2021).

\section{CONCLUSION}

Finite-difference 2D thermo-mechanical numerical experiments have been carried out to model the formation of extensional basins with a pre-rift salt layer to be subsequently shortened by thin-, thick-skinned, and thin- to thick-skinned convergence coeval with surface processes (i.e., erosion and sedimentation). Our results indicate a strong control imposed by the rate of extension and salt rheology on the internal architecture of extensional basins, as well as the degree of estructural decoupling above active extensional faults with a pre-rift salt layer. Syn-extension basin size and distribution is also controlled by the spacing between active basement faults, with faster rates leading to larger partitioning of depocentres separated by salt anticlines or diapirs. The pre-shortening configuration (end-or-rifting and post-rift quiescence) is fundamental in shaping the geometries and kinematic evolution of the subsequent shortening phase. Under the boundary conditions applied in our numerical simulations linear salt viscosities replicated more accurately the geometries observed in natural case studies, particularly in the extensional phases. Widespread presence of magmatic intrusions in evaporites may significantly increase formation viscosity. Including changes in the layered evaporite sequences in terms of the $\%$ of halite or the intercalations of non-evaporitic lithologies may also contribute to changes in formation viscosity. Further analysis using time-integrated geothermal gradients applied to non-Newtonian salt rheologies may aid in providing more accurate numerical simulations, and also establishing a better understanding of the natural long-term behavior of saltrock formations rheology.

The models presented here can be applied to other salt-influenced fold-and-thrust belts where the initial relationships between basement features responsible for crustal stretching/thinning and their sedimentary cover have been lost due to large tectonic transport, such as the Eastern Fars province of Iran, the Pyrenees or the Northern Calcareous Alps, as well as to rift basins with pre-rift salt that had undergone different degrees of tectonic inversion, such as the North Sea or the European Permian Basins.

\section{DATA AVAILABILITY STATEMENT}

The original contributions presented in the study are included in the article/Supplementary Material, further inquiries can be directed to the corresponding authors.

\section{AUTHOR CONTRIBUTIONS}

PG: hypothesis of work, modeling set up, interpretation of results, natural case studies, fieldwork and cross-section construction, manuscript writing and handling, and figure drafting. JR: numerical modeling code write up, experiments run, interpretation of results, manuscript writing, and figure drafting. PSa: interpretation of results, natural case studies, fieldwork and cross-section construction, manuscript writing, and figure drafting. PSt: natural case studies, fieldwork and crosssection construction, manuscript writing, and figure drafting. JM: hypothesis of work, modeling set up, interpretation of results, natural case studies fieldwork and cross-section construction, funding acquisition, and manuscript writing. All authors contributed to the article and approved the submitted version.

\section{FUNDING}

This research has been supported by the project "Tectónica Salina en Cinturones Contractivos"(SALTCONBELT-CGL2017-85532P), funded by Agencia Estatal de Investigación (AEI) and Fondo Europeo de Desarrollo Regional (FEDER). PG and PSa were supported by Fundació Bosch i Gimpera from Universitat de Barcelona. JR was supported by the ETH Zurich.

\section{ACKNOWLEDGMENTS}

This work is a contribution of the Institut de Recerca Geomodels and the Geodinàmica i Anàlisi de Conques research group (2014SGR467SGR), from the Agència de Gestió d'Ajuts Universitaris i de Recerca (AGAUR) and the Secretaria d'Universitats i Recerca del Departament d'Economia i Coneixement de la Generalitat de Catalunya, and the Structural Geology and Tectonics Group, Geological Institute, Department of Earth Sciences, ETH Zürich, Switzerland. Supplementary animations of all experiments can be found in the following link: https://www.research-collection.ethz.ch/handle/ 20.500.11850/458805.

\section{SUPPLEMENTARY MATERIAL}

The Supplementary Material for this article can be found online at: https://www.frontiersin.org/articles/10.3389/feart. 2021.648937/full\#supplementary-material 


\section{REFERENCES}

Albertz, M., Beaumont, C., Shimeld, J. W., Ings, S. J., and Gradmann, S. (2010). An investigation of salt tectonic structural styles in the Scotian Basin, offshore Atlantic Canada: 1. Comparison of observations with geometrically simple numerical models. Tectonics 29:TC4017. doi: 10.1029/2009TC00 2539

Allen, J., and Beaumont, C. (2012). Impact of inconsistent density scaling on physical analogue models of continental margin scale salt tectonics. J. Geophys. Res. Solid Earth 117:B08103. doi: 10.1029/2012JB009227

Allen, J., Beaumont, C., and Deptuck, M. E. (2020). Feedback between synrift lithospheric extension, sedimentation and salt tectonics on wide, weak continental margins. Petrol. Geosci. 26, 16-35. doi: 10.1144/petgeo2018-089

Alves, T., Gawthorpe, R. L., Hunt, D. W., and Monteiro, J. H. (2002). Jurassic tectono-sedimentary evolution of the Northern Lusitanian Basin (offshore Portugal). J. Struct. Geol. 19, 727-754. doi: 10.1016/S0264-8172(02)00036-3

Arboleya, M. L., Teixell, A., Charroud, M., and Julivert, M. (2004). A structural transect through the High and Middle Atlas of Morocco. J. Afric. Earth Sci. 39, 319-327. doi: 10.1016/j.jafrearsci.2004.07.036

Artemieva, I. M. (2011). Lithosphere: An Interdisciplinary Approach. Cambridge: Cambridge University Press, 794. doi: 10.1017/CBO9780511975417

Baudon, C., Fabuel-Perez, I., and Redfern, J. (2009). Structural style and evolution of a Late Triassic rift basin in the Central High Atlas, Morocco: controls on sediment deposition. Geol. J. 44, 677-691. doi: 10.1002/gj. 1195

Beauchamp, W., Allmendinger, R. W., Barazangi, M., Demnati, A., El Alji, M., and Dahmani, M. (1999). Inversion tectonics and the evolution of the High Atlas Mountains, Morocco, based on a geological-geophysical transect. Tectonics 18, 163-184. doi: 10.1029/1998TC900015

Benammi, M., Toto, E., and Chakiri, S. (2001). Les chevauchements frontaux du Haut Atlas central marocain: styles structuraux et taux de raccourcissement différentiel entre les versants nord et sud. Comptes Rendus l'Académ. Sci. 333, 241-247. doi: 10.1016/S1251-8050(01)01628-7

Boyer, S. R., and Elliot, D. (1982). Thrust systems. Am. Assoc. Petro. Geol. Bull. 66, 1196-1230. doi: 10.1306/03B5A77D-16D1-11D7-8645000102C1865D

Burliga, S., Koyi, H. A., and Chemia, Z. (2012). "Analogue and numerical modelling of salt supply to a diapiric structure rising above an active basement fault," in Salt Tectonics, Sediments and Prospectivity, Vol. 363, eds G. I. Alsop, S. G. Archer, A. J. Hartley, N. T. Grant, and R. Hodgkinson (London: Geological Society), 395-408. doi: 10.1144/SP363.18

Callot, J. P., Trocmé, V., Letouzey, J., Albouy, E., Jahani, S., and Sherkati, S. (2012). "Pre-existing salt structures and the folding of the Zagros Mountains," in Salt Tectonics, Sediments and Prospectivity, Vol. 363, eds G. I. Alsop, S. G. Archer, A. J. Hartley, N. T. Grant, and R. Hodgkinson (London: Geological Society), 545-561. doi: 10.1144/SP363.27

Calvín, P. (2018). Paleomagnetic Characterization of Deformational Processes in Intraplate Basins (Central High Atlas): Diapirism, Compression and Igneous Intrusions. Ph. D thesis, Universidad de Burgos, Burgos, 322.

Calvín, P., Casas-Sainz, A. M., Villalaín, J. J., and Moussaid, B. (2018). Extensional vs. compressional deformation in the Central High Atlas salt province: a paleomagnetic approach. Tectonophysics 734-735, 130-147. doi: 10.1016/j. tecto.2018.04.007

Célini, N., Callot, J.-P., Ringenbach, J.-C., and Graham, R. (2020). Jurassic salt tectonics in the SW sub-Alpine fold-and-thrust belt. Tectonics 39:e2020TC006107. doi: 10.1029/2020TC006107

Cohen, C. R. (1982). Model for a passive to active continental margin transition: Implications for hydrocarbon exploration. AAPG Bull. 66, 708-718. doi: 10.1306/03B5A2FF-16D1-11D7-8645000102C1865D

Coleman, A. J., Duffy, O. B., and Jackson, C. A.-L. (2019). Growth folds above propagating normal faults. Earth Sci. Rev. 196:102885. doi: 10.1016/j.earscirev. 2019.102885

Crameri, F., Schmeling, H., Golabek, G. J., Duretz, T., Orendt, R., Buiter, S. J. H., et al. (2012). A comparison of numerical surface topography calculations in geodynamic modelling: an evaluation of the 'sticky air' method. Geophys. J. Int. 189, 38-54. doi: 10.1111/j.1365-246X.2012.05388.x

Davis, D. M., and Engelder, T. (1985). The role of salt in fold-andthrust belts. Tectonophysics 119, 67-88. doi: 10.1016/0040-1951(85) 90033-2
Dooley, T. P., Jackson, M. P. A., and Hudec, M. (2009). Inflation and deflation of deeply buried salt stocks during lateral shortening. J. Struct. Geol. 31, 582-600. doi: 10.1016/j.jsg.2009.03.013

Duffy, O. B., Dooley, T. P., Hudec, M. R., Jackson, M. P. A., Fernandez, N., Jackson, C. A.-L., et al. (2018). Structural evolution of salt-influenced fold-and-thrust belts: a synthesis and new insights from basins containing isolated salt diapirs. J. Struct. Geol. 114, 206-221. doi: 10.1016/j.jsg.2018. 06.024

Duretz, T., Asti, R., Lagabrielle, Y., Brun, J.-P., and Jourdon, A. (2020). Numerical modelling of Cretaceous pyrenean rifting: the interaction between mantle exhumation and syn-rift salt tectonics. Basin Res. 32, 652-667. doi: 10.1111/ bre.12389

Fernández, N., Hudec, M., Jackson, C., Dooley, T. P., and Duffy, O. B. (2020). The competition for salt and kinematic interactions between minibasins during density-driven subsidence: observations from numerical models. Petrol. Geosci. 26, 3-15. doi: 10.1144/petgeo2019-051

Fernández, O., Habermüller, M., and Grassman, B. (2020). Hooked on salt: rethinking alpine tectonics in Hallstatt (Eastern Alps, Austria). Geology 49:30. doi: 10.1130/G47981.1

Frizon de Lamotte, D., Saint Bezar, B., Bracène, R., and Mercier, E. (2000). The two main steps of the Atlas building and geodynamics of the western Mediterranean. Tectonics 19, 740-761. doi: 10.1029/2000TC90 0003

Frizon de Lamotte, D., Zizi, M., Missenard, Y., Hadif, M., El Azzouzi, M., Maury, R. C., et al. (2008). "The atlas system," in Continental Evolution: The Geology of Morocco. Lecture Notes in Earth Sciences, Vol. 116, eds A. Michard, O. Saddiqi, A. Chalouan, D. Lamotte, and F. de (Berlin: Springer), 133-202. doi: 10.1007/978-3-540-77076-3_4

Gerya, T. V., and Yuen, D. A. (2007). Robust characteristics method for modelling multiphase visco-elasto-plastic thermo-mechanical problems. Phys. Earth Planet. Inter. 163, 83-105. doi: 10.1016/j.pepi.2007.04.015

Gillcrist, R., Coward, M. P. A., and Mugnier, J. L. (1987). Structural inversion and its controls: examples from the Alpine foreland and the French Alps. Geodinam. Acta 1, 5-34. doi: 10.1080/09853111.1987.11105122

Gomez, F., Beauchamp, W., and Barazangi, M. (2000). Role of the Atlas Mountains (northwest Africa) within the African-Eurasian plate-boundary zone. Geology 28, 775-778. doi: 10.1130/0091-7613(2000)28<775:ROTAMN > 2.0.CO;2

Gradmann, S., Beaumont, C., and Ings, S. J. (2012). Coupled fluid flow and sediment deformation in margin-scalesalt-tectonic systems: 1. Development and application of simple,single-lithology models. Tectonics 31:TC4010. doi: 10.1029/2011TC003033

Granado, P., Roca, E., Strauss, P., Pelz, K., and Muñoz, J. A. (2019). Structural styles in fold-and-thrust belts involving early salt structures: the Northern Calcareous Alps (Austria). Geology 47, 51-54. doi: 10.1130/G45281.1

Granado, P., and Ruh, J. B. (2019). Numerical modelling of inversion tectonics in fold-and-thrust belts. Tectonophysics 763, 14-29. doi: 10.1016/j.tecto.2019.04. 033

Granado, P., Thöny, W., Carrera, N., Gratzer, O., Strauss, P., and Muñoz, J. A. (2016). Basement-involved reactivation in fold and thrust belts: the AlpineCarpathian Junction (Austria). Geol. Magaz. 153, 1100-1135. doi: 10.1017/ S0016756816000066

Hudec, M. R., and Jackson, M. P. A. (2007). Terra infirma: understanding salt tectonics. Earth Sci. Rev. 82, 1-28. doi: 10.1016/j.earscirev.2007.01.001

Jackson, M., and Hudec, M. (2017). Salt Tectonics: Principles and Practice. Cambridge: Cambridge University Press. doi: 10.1017/9781139003988

Jahani, S., Callot, J. P., de Lamotte, D. F., Letouzey, J., and Leturmy, P. (2007). "The Salt Diapirs of the Eastern Fars Province (Zagros, Iran): a brief outline of their past and present," in Thrust Belts and Foreland Basins. Frontiers in Earth Sciences, eds O. Lacombe, F. Roure, J. Lavé, and J. Vergés (Berlin: Springer), doi: 10.1007/978-3-540-69426-7_15

Lacombe, O., and Bellahsen, N. (2016). Thick-skinned tectonics and basementinvolved fold-thrust belts. Insights from selected Cenozoic orogens. Geol. Magaz. 153, 1-48. doi: 10.1017/S0016756816000078

Laville, E., and Piqué, A. (1992). Jurassic penetrative deformation and Cenozo $\iota$ c uplift in the Central High Atlas (Morocco): a tectonic model. Structural and orogenic inversions. Geol. Rundsch. 81, 157-170. doi: 10.1007/BF01764546

Leitner, C., Weismaier, S., Köster, M. H., Gilg, H. A., Finger, F., and Neubauer, F. (2017). Alpine halite-mudstone-polyhalite tectonites: sedimentology and early 
diagenesis of evaporites in an ancient rift setting (Haselgebirge Formation, eastern Alps). GSA Bull. 129, 1537-1553. doi: 10.1130/B31747.1

Li, S., Strozyk, F., Abe, S., van Gent, H., Kukla, P., and Urai, J. L. (2012). "A method to evaluate long-term rheology of Zechstein Salt in the Tertiary," in Mechanical Behavior of Salt VII, eds P. Berest, M. Ghoreychi, F. Hadj-Hassen, and M. Tijani (London: Taylor \& Francis Group), 215-220. doi: 10.1201/b12041-31

Li, S., and Urai, J. L. (2012). Rheology of rock salt for salt tectonics modeling. Petrol. Sci. 13, 712-724. doi: 10.1007/s12182-016-0121-6

Linzer, H. G., Ratscchbacher, L., and Frisch, W. (1995). Transpressional collision structures in the upper crust: the fold-thrust belt of the Northern Calcareous Alps. Tectonophysics 242, 41-61. doi: 10.1016/0040-1951(94)00152-Y

Mandl, G. W. (2000). The Alpine sector of the Tethyan shelf - examples of Triassic to Jurassic sedimentation and deformation from the Northern Calcareous Alps. Mitteilungen Österreichisch. Geol. Gesellschaft 92, 61-77.

Martín-Martín, J. D., Vergés, J., Saura, E., Moragas, M., Messager, G., Baqués, V., et al. (2016). Diapiric growth within an Early Jurassic rift basin: the Tazoult salt wall (central High Atlas, Morocco). Tectonics 35:4300. doi: 10.1002/ 2016TC004300

Mattauer, M., Tapponnier, P., and Proust, F. (1977). Sur les mecanismes de formation des chaines intracontinentales; l'exemple des chaines atlasiques du Maroc. Bull. Soc. Geol. France S7-XIX, 521-526. doi: 10.2113/gssgfbull.S7-XIX. 3.521

Michard, A., Ibouh, H., and Charrière, A. (2011). Syncline-topped anticlinal ridges from the High Atlas: a Moroccan conundrum, and inspiring structures from the Syrian Arc, Israel. Terra Nov. 23, 314-323. doi: 10.1111/j.1365-3121.2011. 01016.x

Moragas, M., Vergés, J., Saura, E., Martín-Martín, J.-D., Messager, G., MerinoTomé, Ó, et al. (2016). Jurassic rifting to post-rift subsidence analysis in the Central High Atlas and its relation to salt diapirism. Basin Res. 30, 336-362. doi: 10.1111/bre.12223

Moresi, L., Dufour, F., and Muhlhaus, H. B. (2003). A Lagrangian integration point finite element method for large deformation modeling of viscoelastic geomaterials. J. Comput. Phys. 184, 476-497. doi: 10.1016/S0021-9991(02) 00031-1

Moresi, L., Quenette, S., Lemiale, V., Meriaux, C., Appelbe, B., and Muhlhaus, H. B. (2007). Computational approaches to studying non-linear dynamics of the crust and mantle. Phys. Earth Planet. Inter. 163, 69-82. doi: 10.1016/j.pepi.2007.06. 009

Mukherjee, S., Talbot, C. J., and Koyi, H. A. (2010). Viscosity estimates of salt in the Hormuz and Namakdan salt diapirs, Persian Gulf. Geol. Magaz. 147, 497-507. doi: 10.1017/S001675680999077X

Pérez-Díaz, L., Alcalde, J., and Bond, C. E. (2020). Introduction: handling uncertainty in the geosciences: identification, mitigation and communication. Solid Earth 11, 889-897. doi: 10.5194/se-11-889-2020

Poisson, A., Hadri, M., Milhi, A., Julien, M., and Andrieux, J. (1998). "The Central High-Atlas (Morocco). Litho- and chrono-stratigraphic correlations during Jurassic times between Tinjdad and Tounfite. Origin of subsidence," in Peri-Tethys Memoir 4: Epicratonic Basins of Peri-Tethyan Platforms, eds S. Crasquin-Soleau and E. Barrier (Paris: Mémoires du Muséum National d'Histoire Naturelle), 237-256.

Quirk, D. G., and Pilcher, R. S. (2012). "Flip-flop salt tectonics," in Salt Tectonics, Sediments and Prospectivity, Vol. 363, eds G. I. Alsop, S. G. Archer, A. J. Hartley, N. T. Grant, and R. Hodgkinson (London: Geological Society), 245-264. doi: $10.1144 /$ SP363.11

Ranali, G. (1997). Rheology and deep tectonics. Ann. Geophys. 40, 671-680. doi: 10.4401/ag- 3893

Richardson, N. J., Underhill, J. R., and Lewis, G. (2005). The role of evaporite mobility in modifying subsidence patterns during normal fault growth and linkage, Halten Terrace, Mid-Norway. Basin Res. 17, 203-223. doi: 10.1111/j. 1365-2117.2005.00250.x

Roca, E., Ferrer, O., Rowan, M. G., Muñoz, J. A., Butillé, M., Giles, K. G., et al. (2021). Salt tectonics and controls on halokinetic-sequence development of an exposed deepwater diapir: the Bakio Diapir, Basque-Cantabrian Basin, Pyrenees. Mar. Petrol. Geol. 123:104770. doi: 10.1016/j.marpetgeo.2020.104770

Rowan, M. G., and Giles, K. G. (2012). "Concepts in halokinetic-sequence deformation and stratigraphy," in Salt Tectonics, Sediments and Prospectivity, Vol. 363, eds G. I. Alsop, S. G. Archer, A. J. Hartley, N. T. Grant, and R. Hodgkinson (London: Geological Society), 7-31. doi: 10.1144/SP363.2
Rowan, M. G., and Lindsø, S. (2017). "Salt tectonics of the Norwegian Barents Sea and Northeast Greenland shelf," in Permo-Triassic Salt Provinces of Europe, North Africa and the Atlantic Margins, eds J. I. Soto, J. F. Flinch, and G. Tari (Amsterdam: Elsevier), 265-286. doi: 10.1016/B978-0-12-809417-4.00013-6

Rowan, M. G., Urai, J. L., Fiduk, J. C., and Kukla, P. A. (2019). Deformation of intrasalt competent layers in different modes of salt tectonics. Solid Earth 10, 987-1013. doi: 10.5194/se-10-987-2019

Rowan, M. G., and Vendeville, B. (2006). Foldbelts with early salt withdrawal and diapirism: physical model and examples from the northern Gulf of Mexico and the Flinders Ranges, Australia. Mar. Petrol. Geol. 9-10, 871-891. doi: 10.1016/j.marpetgeo.2006.08.003

Rowan, M. G., and Weimer, P. W. (1998). Salt-Sediment Interaction, Northern Green Canyon and Ewing Bank (Offshore Louisiana), Northern Gulf of Mexico. AAPG Bull. 82, 1055-1082.

Ruh, J. B. (2017). Effect of fluid pressure distribution on the structural evolution of accretionary wedges. Terra Nova 29, 202-210. doi: 10.1111/ter.12263

Ruh, J. B. (2019). Effects of fault-weakening processes on oblique intracontinental rifting and subsequent tectonic inversion. Am. J. Sci. 319, 315-338. doi: 10.2475/ 04.2019 .03

Ruh, J. B., Kaus, B. J. P., and Burg, J.-P. (2012). Numerical investigation of deformation mechanics in fold-and-thrust belts: influence of rheology of single and multiple décollements. Tectonics 31:TC3005. doi: 10.1029/2011TC00 3047

Ruh, J. B., and Vergés, J. (2018). Effects of reactivated extensional basement faults on structural evolution of fold-and-thrust belts: insights from numerical modelling applied to the Kopet Dagh Mountains. Tectonophysics 746, 493-511. doi: $10.1016 /$ j.tecto.2017.05.020

Saura, E., Vergés, J., Martín-Martín, J. D., Messager, G., Moragas, M., Razin, P., et al. (2014). Syn- to post-rift diapirism and minibasins of the Central High Atlas (Morocco): the changing face of a mountain belt. J. Geol. Soc. Lond. 171, 97-105. doi: 10.1144/jgs2013-079

Schnabel, W., Fuchs, G., Matura, A., Bryda, G., Egger, J., Krenmayer, H. G., et al. (2002). Geologische Karte von Niederösterreich, 3B1. Vienna: Geological Survey of Austria (GBA).

Soto, J. I., Finch, J., and Tari, G. (2017). Permo-Triassic Salt Provinces of Europe, North Africa and the Atlantic Margins: Tectonics and Hydrocarbon Potential. Amsterdam: Elsevier. doi: 10.1016/B978-0-12-809417-4.00038-0

Stewart, S. A. (2007). "Salt tectonics in the North Sea Basin: a structural style template for seismic interpreters," in Deformation of the Continental Crust: The Legacy of Mike Coward, Vol. 272, eds A. C. Ries, R. W. H. Butler, and R. H. Graham (London: Geological Society), 361-396. doi: 10.1144/GSL.SP.2007. 272.01 .19

Strauss, P., Granado, P., and Muñoz, J. A. (2020). Subsidence analysis of salt tectonics-driven carbonate minibasins (Northern Calcareous Alps, Austria). Basin Res. 58, 1-23. doi: 10.1111/bre. 12500

Tavani, S., Balsamo, F., and Granado, P. (2018). Petroleum system in supra-salt strata of extensional forced folds: a case study from the Basque-Cantabrian basin (Spain). Mar. Petrol. Geol. 96, 315-330. doi: 10.1016/j.marpetgeo.2018. 06.008

Tavani, S., and Granado, P. (2015). Along-strike evolution of folding, stretching and breaching of supra-salt strata in the Plataforma Burgalesa extensional forced fold system (Northern Spain). Basin Res. 27, 573-585. doi: 10.1111/bre. 12089

Tavani, S., Granado, P., Corradetti, A., Camanni, G., Vignaroli, G., Manatschal, G., et al. (2021). Rift inheritance controls the switch from thin- to thick-skinned thrusting and basal décollement re-localization at the subduction-to-collision transition. GSA Bull. doi: 10.1130/B35800.1

Teixell, A., Arboleya, M. L., Julivert, M., and Charroud, M. (2003). Tectonic shortening and topography in the central High Atlas (Morocco). Tectonics 22:1051. doi: 10.1029/2002TC001460

Teixell, A., Barnolas, A., Rosales, I., and Arboleya, M. L. (2017). Structural and facies architecture of a diapir-related carbonate minibasin (Lower and Middle Jurassic, High Atlas, Morocco). Mar. Petrol. Geol. 81, 334-360. doi: 10.1016/j. marpetgeo.2017.01.003

Teson, E., and Teixell, A. (2008). Sequence of thrusting and syntectonic sedimentation in the eastern Sub-Atlas thrust belt (Dades and Mgoun valleys, Morocco). Int. J. Earth Sci. 97, 103-113. doi: 10.1007/s00531-0060151-1 
Torres-López, S., Casas, A. M., Villalaín, J. J., El Ouardi, H., and Moussaid, B. (2016). Pre-Cenomanian vs. Cenozoic folding in the High Atlas revealed by palaeomagnetic data. Terra Nov. 28, 110-119. doi: 10.1111/ter. 12197

Torres-López, S., Casas, A. M., Villalaín, J. J., Moussaid, B., Ruiz Martínez, V. C., and El Ouardi, H. (2018). Evolution of the ridges of Midelt-errachidia section in the high atlas revealed by paleomagnetic Data. Tectonics 37, 3018-3040. doi: 10.1029/2017TC004936

Turcotte, D. L., and Schubert, G. (2002). Geodynamics, 2nd Edn, New York, NY: Cambridge University Press, 863.

Vergés, J., Moragas, M., Martín-Martín, J. D., Saura, E., Casciello, E., Razin, P., et al. (2017). "Salt Tectonics in the Atlas Mountains of Morocco. Permo-Triassic Salt Prov," in Permo-Triassic Salt Provinces of Europe, North Africa and the Atlantic Margins, eds J. I. Soto, J. Flinch, and G. Tari (Amsterdam: Elsevier), 563-632. doi: 10.1016/B978-0-12-809417-4.00027-6
Withjack, M. O., and Callaway, J. S. (2000). Active normal faulting beneath a salt layer - an experimental study of deformation in the cover sequence. AAPG Bull. 84, 627-651. doi: 10.1306/C9EBCE73-1735-11D7-8645000102C1865D

Conflict of Interest: The authors declare that the research was conducted in the absence of any commercial or financial relationships that could be construed as a potential conflict of interest.

Copyright (c) 2021 Granado, Ruh, Santolaria, Strauss and Muñoz. This is an openaccess article distributed under the terms of the Creative Commons Attribution License (CC BY). The use, distribution or reproduction in other forums is permitted, provided the original author(s) and the copyright owner(s) are credited and that the original publication in this journal is cited, in accordance with accepted academic practice. No use, distribution or reproduction is permitted which does not comply with these terms. 